\title{
Machine in the Garden: The Woolen Textile Industry of the Amana Society, 1785-1942
}

\author{
PETER HOEHNLE
}

TEXTILE PRODUCTION was an important part of the economic, social, and cultural life of the Community of True Inspiration from its early days in Germany in the eighteenth century through its existence as a communal society in New York and Iowa from 1843 through 1932. The Amana textile mills were, to borrow a phrase from Leo Marx, "machines in the garden."1 It

I acknowledge the assistance of Pamela Riney-Kehrberg, Leah Tookey, and Dorothy Schwieder of Iowa State University in writing this article, as well as the helpful comments of three anonymous reviewers, the editor of the Annals of Iowa, and the support of the State Historical Society of Iowa through the grant that funded my research. I also acknowledge the help given to me by my family and members of the Amana community.

1. Leo Marx, The Machine in the Garden: Technology and the Pastoral Ideal in America (New York, 1964). Most of the more than 260 communal societies founded in the United States prior to the 1960 s were agriculturally based. A small number of larger groups such as the Amana Society engaged in large-scale manufacturing. Among the more successful were the Oneida Community of New York, which specialized in manufacturing animal traps, chains, and silverware, and the Harmony Society of Pennsylvania, which, like Amana, produced textiles for a wide market. The Zoar Society of Ohio also produced woolens for sale, while the Bethel Society of Missouri became well known for its production of "Golden Rule" whiskey. The various Shaker communities marketed seeds, furniture, and other items commercially. The best brief descriptions of these societies and their activities are in Donald E. Pitzer, ed., America's Communal Utopias (Chapel Hill, NC, 1997). See also Daniel B. Reibel and Rachel P. Maines, "Unlikely Capitalists: Harmonists as Textile Manufacturers," Pennsylvania Heritage 10 (1984), 18-25; Edgar B. Nixon, "The Society of Separatists of Zoar" (Ph.D. diss., Ohio State University, 1933); Edward Deming Andrews and Faith Andrews, Work and Worship among the Shakers: Their Craftsmanship and Economic Order (New York, 1974).

THE ANNALS OF IOWA 61 (Winter 2002). (C) The State Historical Society of Iowa, 2002. 
was striking to see agrarian and industrial life juxtaposed so starkly in Iowa. At the end of the same dirt streets where residents herded cattle every day, only a few hundred feet from the village barns, in tiny communities of fewer than 500 residents each, stood two of the largest woolen mills in the state. The mills employed hundreds of Society members and produced some of the clothing that they wore. Sales of mill goods provided income for the Amana Society to purchase what it could not produce itself. Working conditions in the Society's mills, when compared to those outside the community, suggest that the Society may have achieved the idealized form of labor sought by reformers such as the Scottish industrialist Robert Owen. Finally, the ways outside observers described the mills and their functions reflect common biases held by outsiders toward the community.

THE COMMUNITY OF TRUE INSPIRATION, the religious sect that founded the Amana Society, originated as a Pietistic group in Germany in the early eighteenth century. The original sect, under the leadership of its cofounders, Eberhard Ludwig Gruber and Johann Friedrich Rock, emphasized personal religious expression and humility. The Inspirationists believed that God still communicated through certain chosen individuals, known as Werkzeuge (literally "instruments"). They also considered what the Werkzeuge said while under inspiration as divinely inspired. The group gained in popularity and stature, but declined following Rock's death in 1749.

In 1817 Michael Kraussert, a journeyman tailor from Strassburg, led a revival within the sect. During the revival period two other Werkzeuge, Barbara Heinemann and Christian Metz, emerged. Following internal divisions, Kraussert left the sect and Heinemann ceased speaking in inspiration following her 1823 marriage, after which Metz emerged as the group's sole leader. Through Metz's efforts, the revival spread to the nearly extinct Inspirationist communities throughout the German states and Switzerland. Because Inspirationists refused to serve in the military, send their children to public schools, or swear legal oaths, they came under increasing civil persecution. Consequently, under Metz's direction, the sect leased several large 
estates in the province of Hesse, which provided a refuge for the persecuted faithful. The precise number of Inspirationists living on the four estates by the mid-1830s remains unknown, although a leading authority suggests that the movement as a whole had between two and three thousand adherents prior to emigration. The majority of the Inspirationists on the estates were merchants or artisans, while a smaller number were farmers. Most of the members were apparently literate. ${ }^{2}$

In order to provide employment for those moving to the estates, Metz encouraged wealthier members of the sect, some of whom had previously engaged in textile manufacturing, to establish textile factories on the estates. Textile production had been intimately associated with the Inspirationist community from its earliest days. Several members of the sect, including the Werkzeuge Johann Adam Gruber and Barbara Heinemann, were weavers or producers of cloth. The Inspirationist Trautmann family, residing in the village of Liebloos, probably began the organized production of textiles as early as 1785 . The Trautmann family likely engaged in a form of the verlag, or "putting out" system: a manufacturer provided raw materials to peasant farmers who produced cloth. The manufacturer later returned, paid the producer, and sold the finished product on the open market. Other prominent Inspirationist families, such as the Heinemanns (not related to the Werkzeug of the same name) and Moershels, also engaged in woolen production. ${ }^{3}$

In 1829 Metz directed Friedrich Heinemann to assume management of a spinning works at the Herrnhaag estate "in order to provide poor members with a livelihood." The leadership relocated the operation to a nearby milling facility in 1838 and expanded production in 1840 by beginning a woolen mill at the Armenburg estate. Five Inspirationist elders, including Carl Winzenried and Wilhelm Moershel, who contributed the major-

2. Jonathan Andelson to the author, 8 January 2002; Jonathan Andelson, "The Community of True Inspiration from Germany to the Amana Colonies," in Pitzer, ed., America's Communial Utopias, 187. Membership records predating the communal period were either not kept or are lost.

3. "Einige Nachrichten ueber die Trautmannische Familien" (An Account of the Trautmann Family), unpublished manuscript, n.d., author's collection. 
ity of capital to the firm, chartered this second mill, which became known as "Moershel, Winzenried and Company."4

In 1842, faced with drought, higher rents on the estates, a fuel shortage, and increased pressure from governmental authorities, Metz delivered a testimony to seek refuge in the New World. The Inspirationists received such messages as divinely inspired. Thus, a committee of four, including Metz, was appointed to explore several sites in New York State. They ultimately selected a five-thousand-acre tract on the former Seneca Indian Reservation near Buffalo, New York. Between 1843 and 1846 , more than 800 of the Inspirationist faithful made the hazardous journey to America. Before the migration began, Metz, together with his associate, Wilhelm Noé, produced a provisional constitution, intended to last for two years. During that time members would surrender all assets and property to the Society to enable it to defray the cost of passage for the poorer members and to buy land in New York. In return, interest would accrue on members' money, and the Society would provide them with communal dwellings and food. Metz and his associates viewed the plan as a temporary measure taken to ensure that all members would be able to settle in America. ${ }^{5}$

The Inspirationists named their new settlement "Ebenezer," a biblical term meaning "hitherto the Lord has helped us." As the Inspirationist migration continued, Moershel and Winzenried directed the liquidation of the community's German assets. Terminating the leases on the various estates proved difficult, as the owners of the properties did not wish to lose their beneficial lease arrangements with the Inspirationists. Originally, Moershel and Winzenried intended to sell their woolen machinery, but the miraculous preservation of much of the machinery from a

4. Jonathan Gary Andelson, "Communalism and Change in the Amana Society, 1855-1932" (Ph.D diss., University of Michigan, 1974), 38; "Woolen Mill Contract," 1 June 1840, author's collection. The renting and chartering of the mill facilities and the appointment of mill supervisors were all directed by inspired testimonies issued by Christian Metz. Gottlieb Scheuner, Inspirations Historie, 1817-1850, trans. Janet W. Zuber (Lake Mills, Iowa, 1987), 58, 159.

5. F. Alan DuVal, "Christian Metz: German-American Religious Leader and Pioneer" (Ph.D. diss., State University of Iowa, 1948), 103-5. Metz authored the original draft of the constitution, dated 20 Feburary 1843, which Noé revised. The number of Inspirationists who remained in Germany is unknown. 
fire in December 1843 convinced them that God intended them to take it to America. In June 1844 seventy pieces of machinery were crated and shipped along with Winzenried to America. ${ }^{6}$

The Inspirationists spent their early years at Ebenezer clearing land and building homes, shops, and shelter for the community livestock. Ultimately, the Society established six villages: four in New York and two in Canada. The group intended to be as self-sufficient as possible, thus decreasing its reliance upon, and contact with, the outside world. Complete self-sufficiency was impossible, however, so the Society needed to generate some income to use to purchase goods that it could not produce itself.

THE PRODUCTION OF WOOLEN FABRIC on a large scale filled this need. Anticipation of the potential income from that enterprise led the Society to begin constructing a new factory in 1845 , only two years after first beginning to clear the Ebenezer land. The Inspirationists installed the equipment brought from Germany, apparently with the assistance of a hired American consultant, and, by November 1846, Metz reported, "the spinning machinery is now in operation and produces good yarn." At least sixty men and five women were employed in the Middle Ebenezer factory, suggesting a fairly intensive operation for a village with fewer than five hundred residents.

6. Wilhelm Moershel, Tagebuch, 1843, translation collection, Amana Heritage Society, Amana, Iowa (hereafter cited as AHS); Wilhelm Moershel to Elders, 8 January 1843, trans. Magdalena Schuerer, ibid.; Scheuner, Inspirations Historie, $1817-1850,221,242$. Not all of the machinery was transported. Some was sold to the new management who assumed control of the factory building and operations following the Inspirationists' departure. That firm continued to do business under the name Moershel, Winzenried and Company until its resale in 1871. Heinrich Bier and Eduard Risch, "Letter," 1 October 1871, folder 8, Janet W. Zuber Collection, AHS.

7. Buffalo Inquirer, September 1847; Scheuner, Inspirations Historie, 1817-1850, 242 . The new mill was a three-story wooden structure, measuring $115.5 \times 40$ feet, painted white, with large windows. Around the factory smaller buildings housed a dye house and living quarters for unmarried men who worked in the mill. A water wheel powered the mill and was turned by water from a 1.7mile long millrace, constructed by the Society to channel water from nearby Buffalo Creek. Dimensions from P. Elmslie, "Survey of Ebenezer Lands," unpublished manuscript, lot 51, AHS; Frank Lankes, The Ebenezer Community of True Inspiration (Gardenville, NY, 1949), 49. 


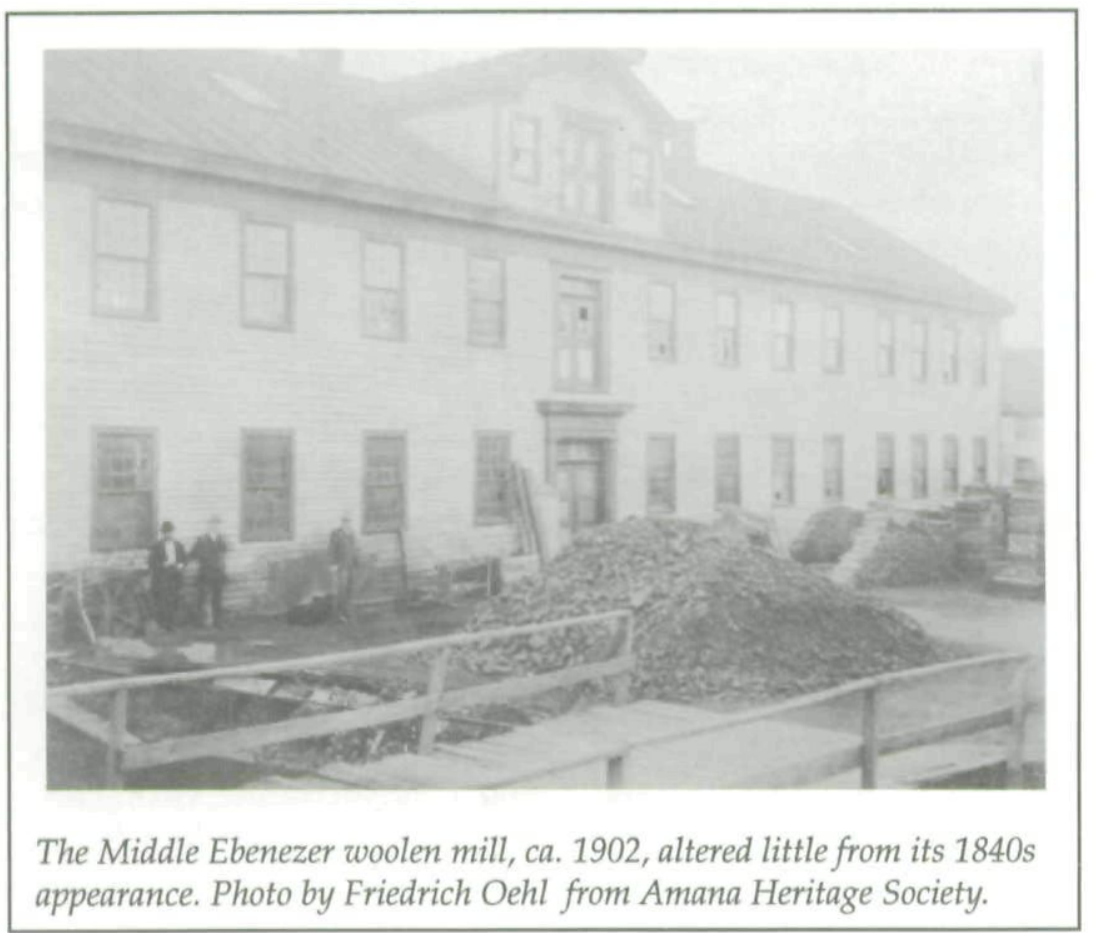

By the time the new mill was in operation, the Society's leaders had decided to make the previously temporary communal arrangement permanent, an end achieved by the new constitution that Moershel and Winzenried drafted. Metz sanctified the constitution by delivering a testimony. Society members adopted and signed the final document in January 1846. Each signing member agreed to renounce his or her property and wages and to accept whatever work assignments the elders gave them. In return, members received a receipt for their assets. They could use the receipt to redeem their property if they chose to leave. The Society also promised members lodging, clothing, food, and other necessities. Members annually elected a thirteen-member Board of Trustees, chosen from the (all male) church elders. The Board of Trustees governed the community, both at Ebenezer and, later, at Amana. Elections were perfunctory; from 1859 through 1932, only one trustee was defeated for reelection. Upon a trustee's death, the board appointed his successor, who, more often than not, continued to serve until his 
own death. Local Bruderraths (or councils) governed each village and most individual and family issues, but major Society decisions belonged to the Board of Trustees, or Grosse Bruderrath. ${ }^{8}$

Initially, the wool that supplied the Ebenezer mill came from the Society's own sheep. The Society's flocks and its methods of tending them attracted the notice of both neighbors and agricultural journalists. The Society divided its 2,000 sheep into flocks, under the attention of shepherds supplied with dogs and portable shelters to use in inclement weather. When necessary, the sheep were housed in large barns, whose interiors were whitewashed four to five times a year in order to "promote health and increase the weight and fineness of the fleece." The Society, however, never produced enough wool to meet the demand of its mills, so, like many woolen manufacturers of the time, it relied on agents and clearinghouses to obtain wool in May of each year. In 1853 the Society spent more than $\$ 20,000$ on wool-a sizable amount for that time.'

The Society sold its woolen products, including yarns, flannels, mittens, stockings, gloves, and wristlets (knitted by the women and children of the community) to a wide range of retail and wholesale companies, including Lord and Taylor in New York and firms as far west as Wisconsin. Much of the Society's

8. DuVal, "Christian Metz," 130-31.

9. The Cultivator, August 1847, 248; Wilhelm Moershel, Tagebuch, 1853; Manufacturing Census, Town of West Seneca, Erie County, New York, 1855. Wool purchases were shipped to Buffalo either by railroad or on the Erie Canal. From there, Society drovers took the wool to the mill, where it was graded and sorted, then run through a picking machine to remove burrs and dirt. Next, workers washed the wool and spread it on frames to dry. After washing, the wool was dyed as necessary, then carded and spun. Several threads of wool, when spun together, produced knitting yarn that the Society marketed along with its other products. Wool yarn that was not spun into knitting yarn was wound on shuttles and used on power looms to weave flannels. The flannel woven by the Society was single-colored, with little or no pattern. After being woven, the flannel was "fulled" (washed to remove the oil and paste used in the spinning and carding processes), and then "napped" (raising the nap of the finished cloth with teasel plant cones fastened to boards under which the cloth was passed). Norman L. Crockett, The Woolen Industry of the Midwest (Lexington, KY, 1970), 80-85. Crockett's description of woolen production is succinct and useful for understanding the Ebenezer mills. For more information on woolen production, see Merrimack Valley Textile Museum, Homespun to Factory Made: Woolen Textiles in America, 1776-1876 (North Andover, MA, 1977). 
trade was with firms owned by German-speaking merchants, suggesting that it cultivated a niche market with merchants who, like themselves, were more comfortable communicating in their native language. ${ }^{10}$

By 1852 , the increasing popularity of the Society's products led the elders to authorize construction of a second woolen factory and settlement, "New Ebenezer," to be located roughly equidistant between the villages of Upper and Middle Ebenezer. The new factory was slightly larger than the Middle Ebenezer facility and was powered by cast iron turbines that sat in a millrace cut through solid rock from Buffalo Creek. ${ }^{\text {.1 }}$

In constructing the new factory, the Society made extensive use of hired, non-member labor. The Society commonly relied on outside workers during the Ebenezer period; several of its structures were built by hired labor, and hired men worked in the mill's dye house as early as 1848 . Presumably, the availability of experienced German-speaking workers in the Buffalo area allowed the Society to hire them for such needs, freeing its own work force to concentrate on production. Ironically, the New Ebenezer factory was not functional by the time the Society began to relocate to its new settlement in Iowa, rendering the effort involved in its planning and construction fruitless. ${ }^{12}$

10. The Society's trade with German-speaking merchants is documented in correspondence contained in two large "letterpress books" in the author's collection. The surviving letterpress books cover the years 1854-1862. Books of this type were commonly used in the nineteenth century to maintain copies of business correspondence. The original letter would be placed under one of the blank leaves of the copy book, and a wet cloth laid on the top, thereby wetting the original letter and producing an ink impression of it on the page.

11. Minutes, Trustees of the Ebenezer Society, 6 April 1852, AHS; Gottlieb Scheuner, "Inspirations Historie, 1852," trans. Virginia Lewis, unpublished manuscript, 12, AHS. When completed, the New Ebenezer woolen mill was an L-shaped brick structure, with wings of $132 \times 34$ feet and $108 \times 38$ feet. P. Elmslie, "Plat of Ebenezer Villages," 105 (lot 27).

12. Minutes, Trustees of the Ebenezer Society, 13 September 1848 . According to the 1855 Manufacturing Census, Town of West Seneca, Erie County, New York, the new factory, valued at $\$ 4,500$, was "not yet in running order." No known image of this factory survives. The mill burned sometime between the Society's removal to Iowa and 1880. The millrace was 2.3 miles in length. Illustrated Atlas of Erie County, 98. At its height, New Ebenezer contained nine houses, a store, a carpenter shop, a barn and stable, the woolen mill, and a dye house. Lankes, Ebenezer Society, 83. 
BY 1854, SOCIETY LEADERS, particularly Christian Metz, had begun to consider relocating to a more isolated location. During the twelve years the Society resided near Buffalo, the city's population mushroomed, from 18,213 in 1840 to 74,214 by 1854 . Approximately 31,000 of those residents were German, and the city's vibrant German community offered enticements to younger members of the Society who may have become tired of the restrictions of communal life and anxious to earn wages. In a letter to a friend in Germany, Metz suggested that the leaders of the Society were led to consider relocation because "we love ... seclusion and privacy ... and [Buffalo] is not a good influence on our young people." Traditionally, histories of the Society have also suggested that a major impetus for its decision to relocate was a need for additional farmland. That is unlikely, however, for by 1855 the Society had cleared only 2,500 acres of the 7,636-acre Ebenezer tract. ${ }^{13}$

Recent discoveries among previously unexamined records suggest other, more menacing reasons for the relocation. By 1855 the Inspirationists, on their large parcel of improved land, maintained two well-equipped woolen mills, a calico print mill, two saw mills, an oil mill, a gristmill, and a tannery. All of these businesses were fairly profitable and competed with similar businesses in neighboring communities that had to pay their workers. Gates blocked the roads that led to Ebenezer, and people who did not have a reason to be there were directed to follow detours around the villages. Under those circumstances, neighbors naturally may have viewed with suspicion a group that appeared so prosperous and secretive. ${ }^{14}$

The mid-1850s were filled with anti-immigrant rhetoric, particularly in Buffalo, where nativists targeted the large, insular German immigrant community. Although there were no documented physical attacks on Buffalo's Germans, rhetoric in the city

13. Andelson, "Communalism and Change," 57; Ehrlich, "The Development of Manufacturing," 278; Mark Goldman, High Hopes: The Rise and Decline of Buffalo, New York (Albany, NY, 1983), 72; Buffalo Commercial Advertiser, 18 May 1855; Christian Metz to Mr. Fabricus, 5 November 1855, trans. Magdalena Schuerer, translations collection, AHS; Lankes, Ebenezer Society, 124.

14. J. H. French, Gazetteer of the State of New York (Syracuse, NY, 1860), 293; Lankes, Ebenezer Society, 97-98. 
papers and other ominous signs "made it difficult for the city's Germans and Irish to feel particularly safe, stable and secure." Such hostility directed toward the Society by its neighbors likely suggested the possibility of relocation to the Inspirationists. ${ }^{15}$

Two incidents suggest that outsider hostility may have influenced the Society's decision to leave. The first involved a dispute with the Buffalo Hydraulic Association, which had built a dam on Buffalo Creek in 1828, approximately $1 \frac{1}{2} 2$ miles from Ebenezer. By 1854, the Ebenezer Society, together with neighboring farmers, had begun to complain openly about the dam, alleging that it caused their farmland to flood and allowed snags to accumulate in the creek, creating stagnant areas that led to a marked increase in illness among residents. They also charged that the flooding hindered the operation of their water-powered machinery. On August 29, 1854, the Association, perceiving a threat from the Society, obtained a court injunction preventing the Society from destroying or damaging the dam. Although Metz did not know it at the time, that was the same day that he issued the order for the Inspirationists to relocate in the West. ${ }^{16}$

At the same time as the Society was engaged in a court battle with the Hydraulic Association, its neighbors charged that it was not paying its fair share of taxes, leading to an investigation of the sect by the State of New York. Society agent Charles Mayer appeared before a special committee in the state capital in March 1855, but the matter appears to have been dropped soon

15. Goldman, High Hopes, 115, 117. The city's favorite son, Millard Fillmore, was the nominee of the anti-immigrant and anti-Catholic American Party, or Know Nothing Party, in 1854 . Goldman is the only author to make a connection between the departure of the Ebenezer Society and anti-foreign sentiment, which, in his assessment, was the major reason for their departure.

16. Frank Lankes, "The Hydraulics," Niagara Frontier (Spring 1955), 8-9; Scheuner, "Inspirations Historie, 1852"; "The Buffalo Hydraulic Association vs. the Village of Ebenezer," 29 August 1854, Supreme Court, Erie County, New York, author's collection; Hugh Cameron, "Defendant Answer in Buffalo Hydraulic Association against the Trustee of the Village of Ebenezer and others," 27 October 1854, ibid. The Supreme Court of Erie County revoked the injunction against the Society that October. Justice R. P. Marvin, "Opinion in the Buffalo Hydraulic Association against the Village of Ebenezer and Others," 1854, ibid. The Hydraulic Association's dam remained in operation until the 1880s, despite the complaints lodged against it. Lankes, Ebenezer Society, 117-18, is the only source to deal with the Hydraulic Association situation as a factor in the Society's decision to leave Ebenezer. 
after. $^{17}$ In a climate in which neighbors openly challenged the Society in various ways, the decision to relocate to a more isolated area, away from outsiders and "worldly" influences, becomes more understandable.

On the night of August 27, 1854, Christian Metz wrote in his diary, "there arose in me a powerful feeling that we must leave Ebenezer and God spoke to me telling me [so]. . . . I told some brothers in confidence about this." On August 29 Metz delivered a testimony stating that the community should relocate in the West. On September 8, 1854, only ten days after that testimony, a committee that included Metz left to examine the Territory of Kansas. After a fruitless search, the committee returned, and a second committee set out for the new state of Iowa. There they located a suitable tract of land in the Iowa River valley, approximately twenty miles west of the state capital at Iowa City. ${ }^{18}$

The Society immediately began the process of liquidating its New York holdings and relocating to Iowa. Because of the Panic of 1857 and the Civil War, it took ten years to sell all of the Ebenezer property. During that time, parties of the faithful journeyed by train to the newly purchased site in Iowa. Through careful management, the Society was able to sell the Ebenezer property at a profit, although the protracted land sale forced them to draw substantial loans from Buffalo banks in order to continue construction of the new Iowa settlement, which Metz named Amana, a biblical word meaning "remain true."19

17. Buffalo Commercial Advertiser, 18 May 1855; W. W. Weed, David O'Keefe, and John Bennett, Committee, to Charles L. Mayer, 21 March 1855, author's collection; Metz, Tagebuch, 1 April 1855. According to Metz, Winzenried accompanied Mayer to the hearing. Metz also noted that their interrogator, a man named White, was from Buffalo and "has been brought up to not like our community. His questions were very hateful and he alleged many items. He sent [Mayer and Winzenried] home knowing that this was by no means over." Apparently, nothing more came of the issue, since neither Metz nor any other source alludes to further investigations. Metz, Tagebuch, 1 April 1855.

18. Gottlieb Scheuner, "Inspirations Historie, 1854," unpublished manuscript, trans. Virginia Lewis, AHS, 6; Metz, Tagebuch, 27 August 1854; Christian Metz, "Testimony \#40, Middle Ebenezer, New York, 29 August 1854," in Sammlung 29 (Amana, Iowa, 1868), 216-17. Metz did not realize, nor have scholars noticed until now, that Metz issued his testimony on the same day as the Hydraulic Association obtained its injunction against the Society.

19. The term Amana is found in Song of Solomon, 4:8. 
WITHIN SEVEN YEARS of first arriving in Iowa in 1855, the Society acquired 26,000 acres of land and laid out seven villages. Because of its central importance to the financial well-being of the early Amana settlers, construction of a new woolen mill was a high priority. The earliest surviving map of the village of Main Amana, from 1858, shows the first, temporary home of woolen mill operations, a wooden $U$-shaped building housing a factory area, a dye house, a wood shop, and a steam engine. ${ }^{20}$

A woolen factory in Iowa in the late 1850 s was a novelty. At that time, machinery production of textiles was only beginning to gain a foothold in the Hawkeye state. Indeed, much of the production of the existing frontier mills was in carding wool for farm families who then spun or wove it themselves. In 1857, while the Society was preparing to construct its mill, only five woolen mills operated in Iowa. Woolen production in the state experienced a momentary rise during the 1860s, but declined sharply after 1870 . Although smaller woolen mills later operated in the nearby communities of Marengo and Coralville, for most of their years of operation, the Amana woolen mills were not only among the very largest in the state, but also among the very few..$^{21}$

By July 8, 1860, Metz reported to those elders who remained in Ebenezer that construction of the new permanent factory at Amana had begun. Built of sandstone, the new facility, when completed, stood three stories high with large windows to provide illumination for the workers. In 1863 the Society constructed a second facility, built of brick, at Middle Amana. Although production forms would change through time, the mill at Main Amana primarily specialized in flannel and yarn production while the mill at Middle Amana produced blankets and more intricate weaves. Combined, the mills contained 6 sets of cards,

20. Map of the Village of Amana, 1858, map collection, AHS.

21. Jacob A. Swisher, Iowa: Land of Many Mills (Iowa City, 1940), 121, 123; Pauline Lillie, Marengo the County Seat, Marengo the Town: A History (Marceline, MO, 1984), 143-44. In 1857 there was one woolen factory in Des Moines, one woolen mill each in Jackson and Wapello Counties, and two in Mahaska County; Henry County recorded four carding machines and two fulling mills. Clara Mirian Evans, "Labor in Iowa, 1850-1860" (M.S. thesis, Iowa State College, 1930), 30-31. 


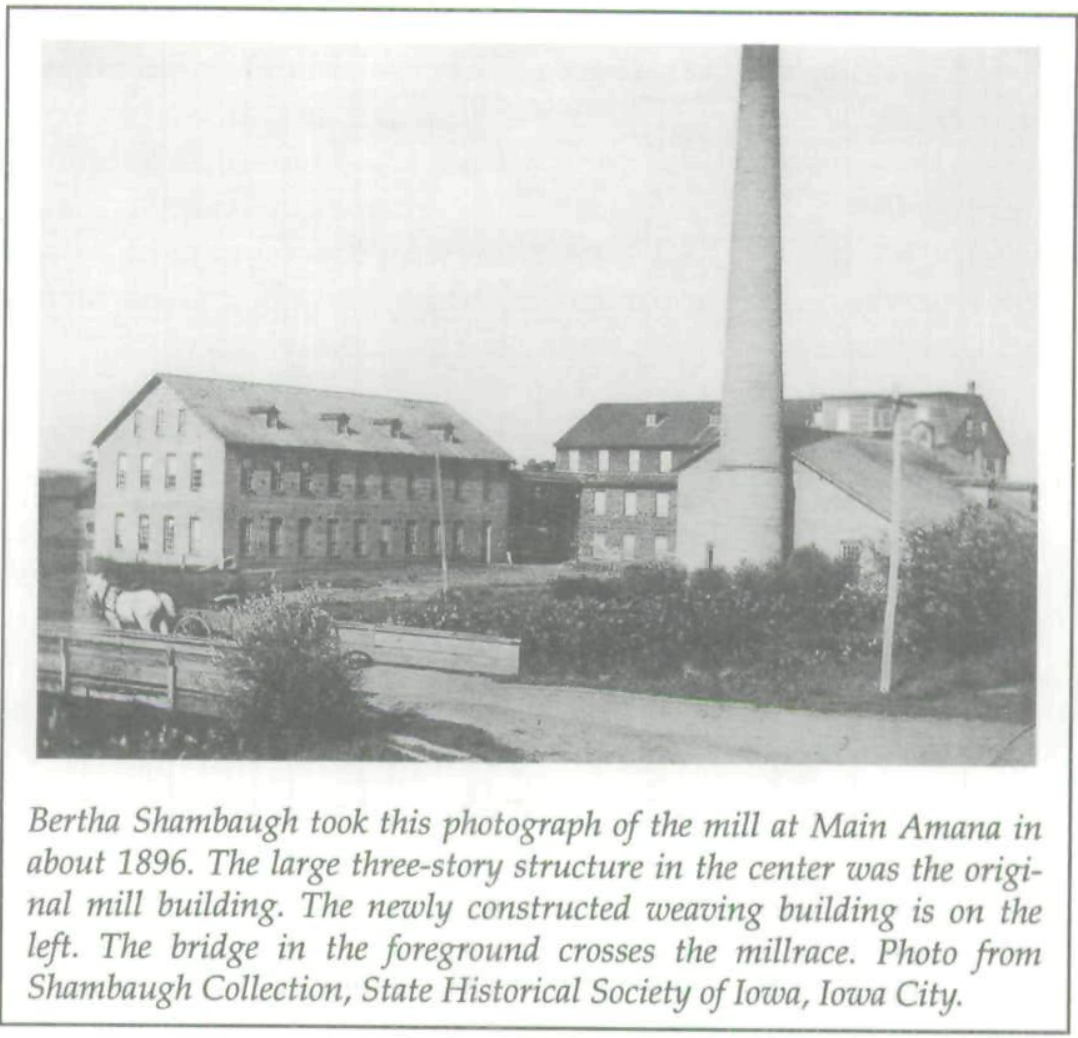

8 spinning hacks, 1,600 spindles, and 20 looms. By 1865, the Ebenezer lands had been sold, and the Society had completely transferred its now 1,300 members and industrial capacity to the Iowa prairies. ${ }^{22}$

Although Society leaders initially expected nearby Price Creek to power the mills, they quickly realized that the slowmoving stream was inadequate. Instead, the leaders turned to the meandering Iowa River that cut through the heart of their property and, in 1865, began to construct a seven-mile-long millrace. When completed in 1869, the millrace was the longest one in Iowa. It supplied water not only to both woolen mills,

22. Christian Metz to Ebenezer Elders, 8 July 1860, quoted in Gottlieb Scheuner, Inspirations Historie, 1817-1867 (Amana, 1891), 668; Davenport Daily Gazette, 29 June 1867. This newspaper article is the earliest known account of Amana by an outsider. 
but also to the Society's calico mill, saw mills, starch mill, threshing equipment, and a large flour mill at Main Amana. ${ }^{23}$

One of the Society's major concerns about the factories was the threat of fire. The Board of Trustees voiced that concern as early as December 1867, when they admonished workers in the Society shops and mills to move flammable materials away from stoves and open fires. At first, the board left the issue of smoking in the workplace up to individual workers, although it "strongly urge[d] them to quit." But when the board banned the burning of kerosene in the factories in October 1871, it also banned smoking, a prohibition that extended not only to the factories, but also to craft shops, saw mills, and barns. As a precaution against fire, the Society constructed two watchtowers near the factories in which young men took their turns as night watchmen. ${ }^{24}$

Despite the precautions, both of the woolen mills burned during the communal period, the Middle Amana mill in 1874 and again in 1881 and the Main Amana mill in 1923. The first fire occurred at the Middle Amana facility on Sunday morning, June 28,1874 . Society leaders attributed the blaze to either "spontaneous combustion" or careless smoking by workers. Mill workers were able to enter the lower floor of the facility and remove flannel and yarn, but little could be saved from the third floor, mainly occupied by machinery. Termed "the greatest disaster" faced by the community up to that time, the fire consumed the main building as well as the wash and engine houses. Although the boilers and the steam engine suffered little damage, the loss was calculated at $\$ 50,000$, about a third of the total value of the facility. The Society quickly overcame the devastating loss and rebuilt the mill. ${ }^{25}$

23. Emilie Zuber Hoppe, "How They Built the Millrace," in The Amana Colonies (Amana, 1993), 21; Terry Trimpe, "The Building of the Amana Mill Canal," unpublished paper, folder 1965, box 3, Amana Community Schools Collection, AHS.

24. Minutes, Trustees of the Amana Society, 3 December 1867 and 2 October 1871. The fire tower in Main Amana was located at the head of the street leading to the factory, where it also had a clear view of, and was adjacent to, the village barn complex. In Middle Amana, the tower stood at the bottom of the village hill, near the factory.

25. The order to rebuild occurred at a Board of Trustees meeting on July 2, four days after the fire. Minutes, Trustees of the Amana Society, 2 July 1874. 
On August 8, 1881, a second fire, beginning in the wool storage area, also attributed to "spontaneous combustion," destroyed the main building of the Middle Amana factory and most of its contents. The efforts of the various village fire crews, along with a lack of wind, kept the fire from spreading to surrounding outbuildings. The Board of Trustees convened on the afternoon of the fire to discuss plans for rebuilding. Barbara Heinemann Landmann, the 86-year-old Werkzeug of the community, and Christian Metz's successor as spiritual leader, presented a testimony at the meeting. The fire, according to the testimony, was a "strike" against the community because of its spiritual decline. The testimony advised the community to "go deep into the valley of humility" in order to initiate a spiritual revival. It also castigated the community and its leaders for demonstrating more concern about the temporal and material issues represented by the loss than for the spiritual decline that made the warning call necessary. ${ }^{26}$

The rebuilt Middle Amana facility opened nine months later on April 27, 1882, following a ceremony unique in the history of the Inspirationists. The Society held a special hour-long prayer gathering attended by the factory workers, the Middle Amana elders, and trustees. At the gathering, the elders consecrated the building through open prayer, stressing the importance of the mill for the spiritual as well as temporal survival of the Society. There is no record of any similar service ever being held in the Amanas. Even newly completed meetinghouses apparently were not consecrated at the first services held in them. Perhaps the elders devised the special consecration ceremony in response to the harsh criticism in Landmann's testimony. Because of the Society's pietistic deemphasis of places of worship, it is unlikely that either the elders or the workers viewed the Middle Amana factory as consecrated space. Rather, they were simply invoking God's blessings on an enterprise that had been visited by fire twice within seven years. ${ }^{27}$

26. Barbara Heinemann Landmann, "Testimony \#22," 9 August 1881, in Sammlunge 53-56 (Amana, 1881), 61-68. I am grateful to Elder Jon Childers of the Amana Church Society for his translation of this important source.

27. The trustees in attendance were all members of the Winzenried family so intimately associated with the management of the Society and its textile industry. Following this second rebuilding of the Middle Amana facility, no other fires 
During the late 1880 s and early 1890 s the Society significantly expanded and modified its textile facilities. At Middle Amana, workers installed a larger steam engine, which necessitated construction of a taller smokestack in order to increase the draw on the steam boilers. Six years later a similar engine and smokestack were installed at the Main Amana facility, replacing smaller versions of the same equipment. The Society installed a another smokestack and steam engine at the Main Amana calico factory. The expansions represented not only the Society's improving economic stability but also an advance in technology and a desire to expand production. At Main Amana a new weaving building was erected in 1891 and then nearly doubled in size within twelve years. ${ }^{28}$

From the 1890s onward, the smokestacks of the calico and woolen mills dominated photographs of the villages of Main and Middle Amana. The incongruity of these industrial features towering over the peaceful villages and the acres of vegetable gardens planted to support the village kitchen houses does not appear to have struck outside observers. Such observers, as historian Lanny Haldy has noted, continued to extol the "garden community" aspect of the villages, even when faced with towering evidence to the contrary. ${ }^{29}$

occurred there, although the buildings were ultimately destroyed by fire after the mill was no longer in operation.

28. Gottlieb Scheuner, Inspirations Historie, 1884-1891 (Amana, 1918), 809; Norman L. Crockett, The Woolen Industry of the Midwest (Lexington, KY, 1970), 63. Machinery for the new buildings was purchased from various firms, among them Davis and Furber, an equipment company in North Andover, Massachusetts, that later used the Amana Society's reputation and its faithful association with their firm in its advertising. Davis \& Furber Machine Co., "Purchased in 1854 by the Ebenezer Society," folder 5, box 1, Amana Society Woolen Mill Collection, AHS. Tradition suggests that Amana workers modified and improved upon the machinery in the factories but that their policy of not patenting those inventions allowed others to copy them without benefit to the Society. Lack of documentation, however, makes such assertions impossible to confirm. A single patent was issued to longtime mill worker and community leader George Bernhardt for improvements in carding machine design. Allan W. Ricker, The Amana Society: A Study in Co-operation, from the Viewpoint of a Socialist (Girard, KS, 1908), 34; George Bernhardt, "Patent \#236,408, 11 January 1881," copy, Amana Society Woolen Mill Collection, AHS.

29. Lanny Haldy, "In All the Papers: Newspaper Accounts of Communal Amana, 1867-1924," Communal Societies 14 (1994), 20-35. 


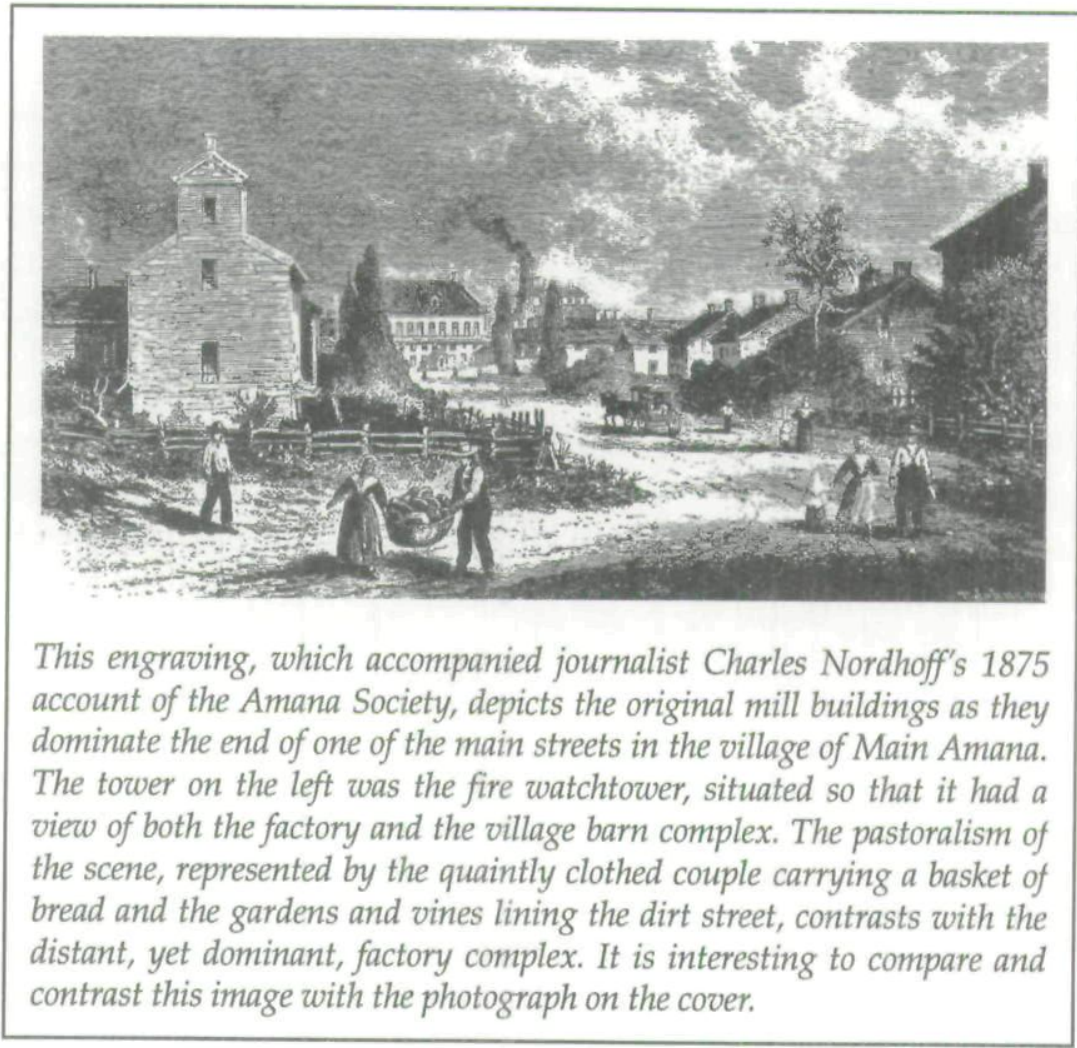

The focus on the bucolic, rural, and natural features of the community is particularly evident in the ways outside authors treated its industrial aspects. Even in an article purportedly on the economic and industrial aspects of the community, one author could not help but note that "it is safe to say that nowhere in the state of Iowa are there as many blossoms per square foot in July and August as there are in the Amana villages." This same observer, in another account that otherwise completely ignored the factory while extolling other aspects of village life, such as happy schoolchildren and flower gardens, did describe "the millrace, with its fringe of grape vines and pickerel weed and the quaint little bridges that span it here and there, [that] is as pretty as it is useful, and furnishes a never ending source of enjoyment for Amana summer visitors." Those observers who did mention the mills in their accounts often interpreted them 


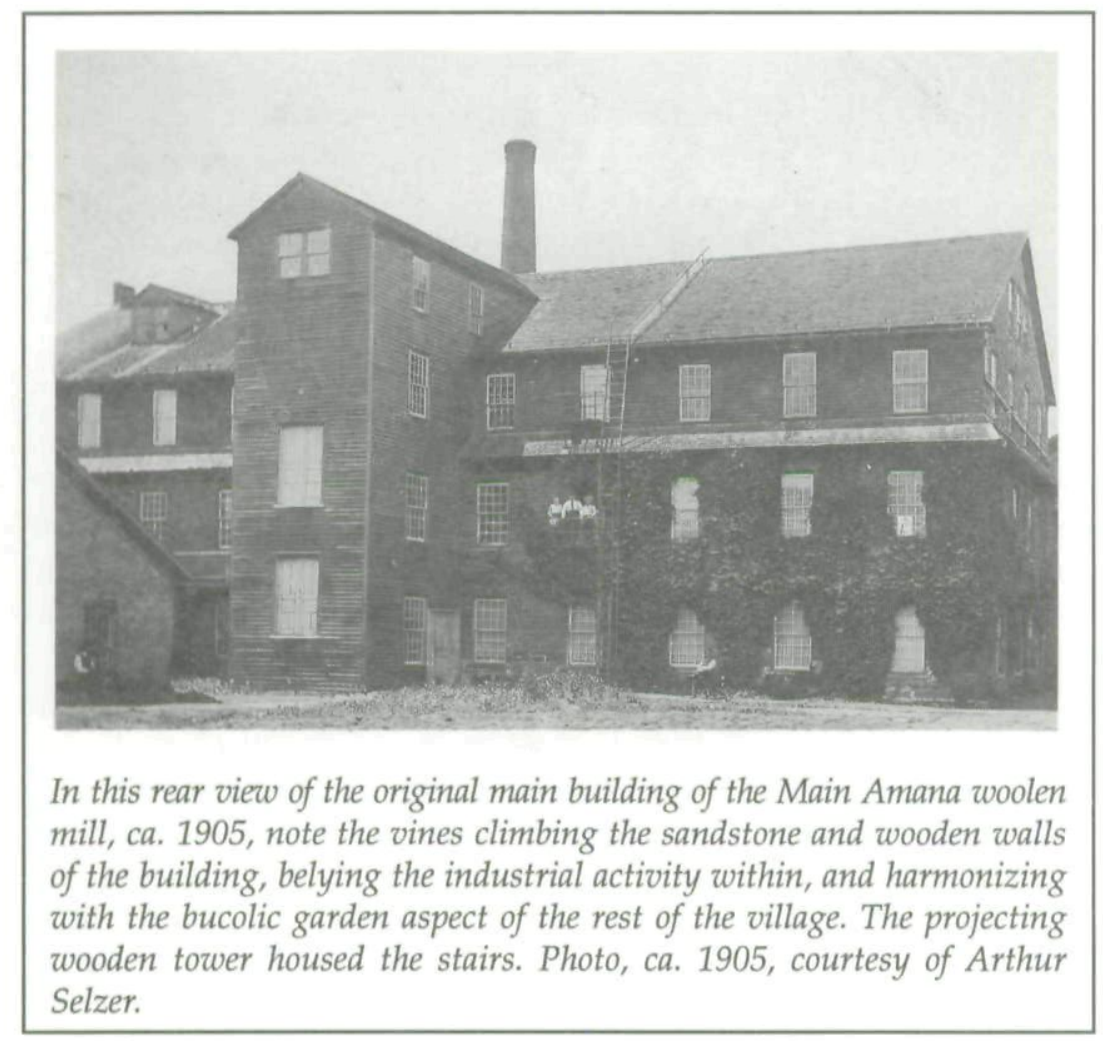

in such a way as to reinforce the garden image of the community. In 1917, for example, an author wrote, "as the busy hum of yonder factory ceases its labor for the day, a stream of sturdy brethren emerges from its doors, and leisurely wends its way toward the little church for the regular evening prayer meeting." The stone and brick mill buildings themselves, covered with vines, were picturesque and suggestive of a garden..$^{30}$

30. Bertha M. H. Shambaugh, "Some of the Economic and Industrial Phases of the Amana Society or the Community of True Inspiration," Ninth Biennial Report of the Bureau of Labor Statistics for the State of Iowa, 1899-1900, 509; Bertha M. Horak, "Amana Colony: A Glimpse of the Community of True Inspiration," Midland Monthly, July 1896, 27; Cedar Rapids Gazette, 24 June 1917. Carl G. Neubauer, who worked in the Main Amana dye house at the turn of the century, noted in his diary when he trimmed the climbing "Virginia creeper" on the side of the building. Neubauer, Diary, 23 May 1911, Personal Account Books Collection, AHS. 
PERHAPS the incongruity of a factory in a place that outside observers wanted to be a garden or a worker's paradise led to questionable claims about Amana's economic enterprise. Many observers of the Society realized by the late 1890 s that they were describing what one of them referred to in a national magazine as "the largest and strongest communistic settlement in the entire world" at the time. ${ }^{31}$ Fired with reformist and utopian zeal, such observers tried to find in Amana a solution to the problems facing late nineteenth-century America.

Unlike the early nineteenth-century utopian visionary and Scottish industrialist Robert Owen, Inspirationist leaders never consciously attempted to create a model industrial facility. They simply wished to produce a quality product that would find a ready market and provide the Society with income. Amana mill workers were almost casual about their work, knowing that the hired hands would compensate for their own deficiencies in output. Because they received no wages, Amana mill workers, unlike workers in the outside world, were not driven by the need for wages. Although they received bonus credits at the village store for overtime, woolen mill workers otherwise received the same allotments of clothing, food, and housing facilities as their counterparts in farm work. And they received those benefits regardless of their individual output.

To the outsider, the relaxed atmosphere in the mills seemed to fulfill a utopian vision. Observers reported seeing vases of flowers in the factory windows and operatives singing hymns at their looms. Ample break rooms existed at both the Main Amana and Middle Amana facilities. In 1888 Albert Shaw observed, "everybody in [these mills] is industrious and cheerful, while nobody is overworked." Henry A. Wallace, who visited the Main Amana woolen mill in 1914, repeated Shaw's observation. "The mill hands," Wallace wrote, "were not 'hurting themselves' by too much work, but looked placid and contented. There was a coffee pot in the center of the room, and one man took time off to pour himself a cup. Everyone was working, but there was not the vigorous bustle noticeable in most American

31. Richard T. Ely, "Amana: A Study of Religious Communism," Harper's 105 (October 1902), 659. For a comparative assessment, see William A. Hinds, American Communities and Cooperative Colonies (Chicago, 1908), 301. 


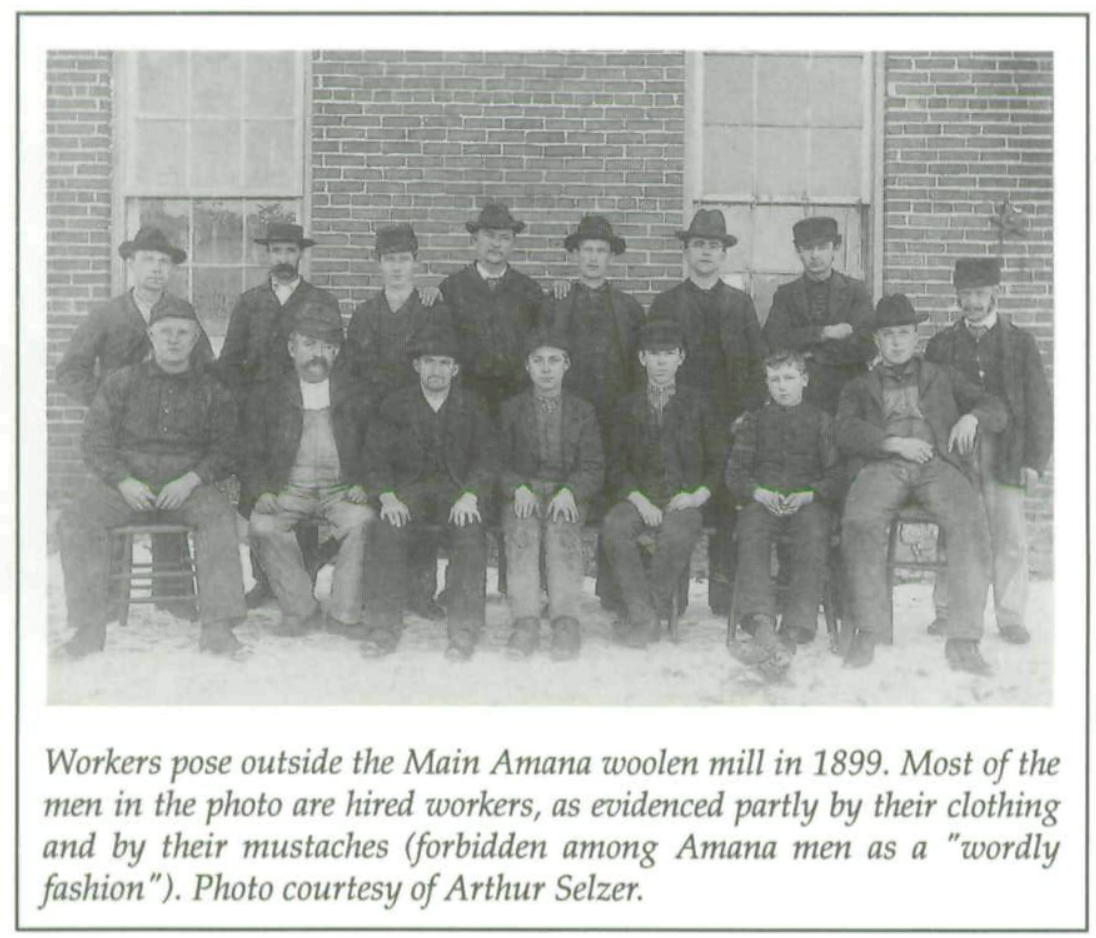

factories." As another observer noted, "there are no drones in this hive. Everyone is busy, but no one is hurried." ${ }^{\prime 32}$

Not all of the mill workers were members of the Society. In 1900 Bertha Shambaugh reported that the woolen mills' 125 employees included not only Society members chosen by church leaders to work there, but 16 to 18 outsiders as well. At the calico print works, where the Society printed designs on muslin

32. Albert Shaw, "Life in the Amana Colony," Palimpsest 52 (1971), 170 (reprinted from The Chautauquan, February 1888); Henry A. Wallace, "Visiting the Amana Society," Wallaces' Farmer 39 (25 December 1914), 1683; Horak, "Amana Colony," 34. Other observers made similar remarks. See, for example, Charles Nordhoff, The Communistic Societies of the United States (1875; reprint, New York, 1961), 141-42, who notes that the Shakers, too, "do not toil severely." The recurrence of this theme in accounts of other communal societies suggests that a comparatively relaxed work style was a defining characteristic of such groups. More work needs to be done on this issue. To date, few scholars have examined working conditions in communal societies, and most who have offer merely descriptive accounts. See, for example, Lawrence Rettig, "Work in the Amana Colonies," in Utopian Visions of Work and Community (Iowa City, 1996), 85-92. 


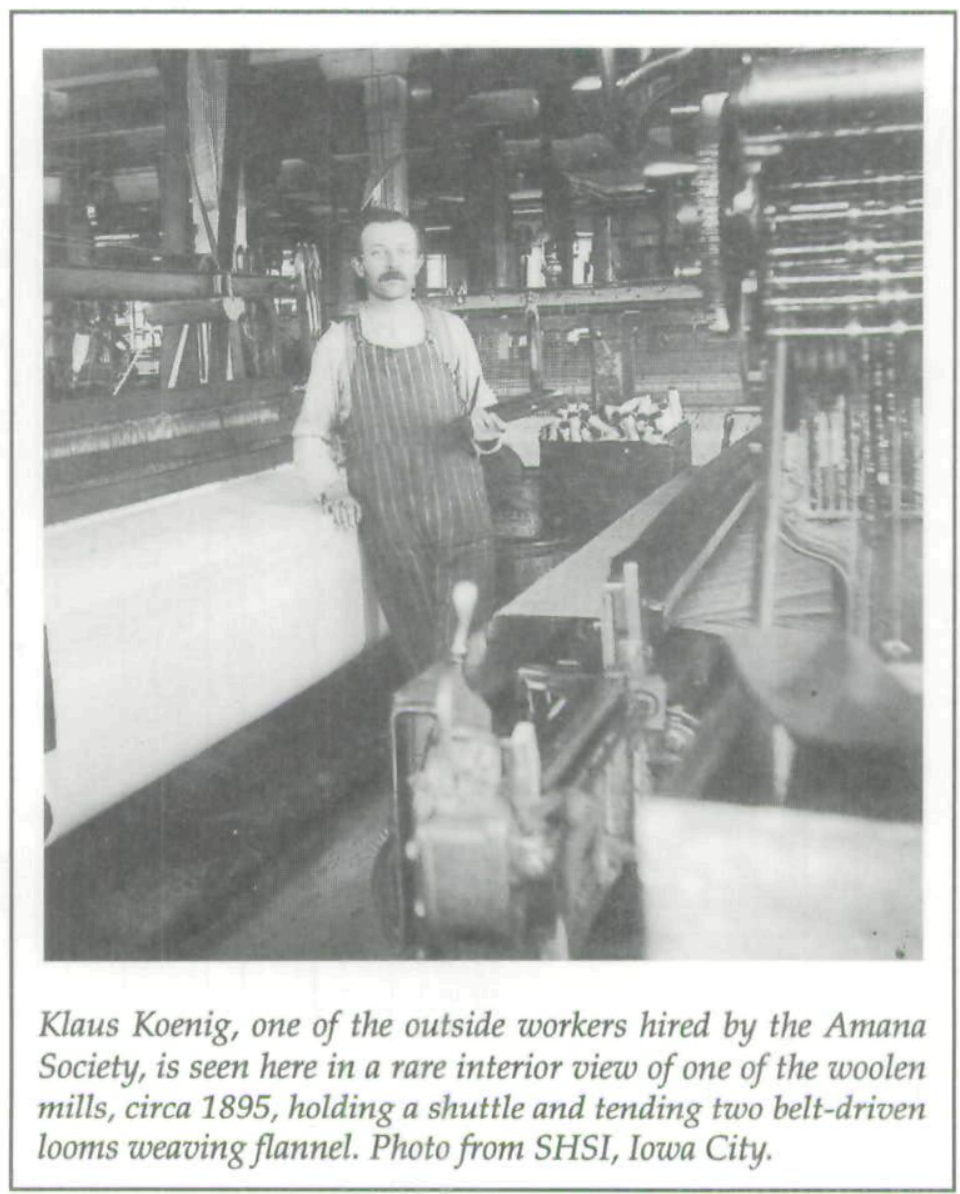

fabric shipped from the South, half of the work force were hired laborers, many of whom lived in a wooden dormitory built next to the factory. These workers, like most of the outside workers the Society hired, spoke German, were male, and often worked for the Society for years or even decades. Although, as in the case of outside farm laborers, the Society generally paid hired workers less than they could obtain outside, most told observers that the other benefits the Society provided, including food and shelter, made up for the difference. ${ }^{33}$

33. Shambaugh, "Some of the Economic and Industrial Phases of the Amana Society," 505. Shambaugh reported exactly the same figures, and indeed reused much of the same text, in her 1908 history of the Amana Society. 
Hired workers tended to do the so-called "dreck work" or "dirty work," such as hauling loads around the factory and stoking the boilers in the firehouse. Most observers reported that only members performed skilled labor such as running looms. Contemporary evidence and the memories of Amana residents, however, suggest that at least some hired workers were skilled workers, such as weavers. Outside observers contrasted the lax Society workers with the more industrious hired hands. In 1875 journalist Charles Nordhoff reported, "the members do not work hard. One of the foremen told me that three hired hands would do as much as five or six of the members." Nordhoff's observation was confirmed by other visitors throughout the Society's communal period..$^{34}$

The number of female workers was apparently low. Working in the woolen mill, primarily spinning broken threads together or inspecting cloth, was, along with serving as a knitting instructor in the schools, a midwife, or providing child care, one of the few occupations open to Amana women that was not linked to the enormous kitchen houses and gardens that supplied food for the villages. The lack of women in the Amana mills was atypical for the time. In 1894, for example, the Flint Mills of Michigan employed 24 women in a total work force of 58; and most southern textile mills made extensive use of women and children. Observers generally applauded the extent to which the Amana mills departed from the norm in this matter. ${ }^{35}$

34. Bertha M. H. Shambaugh, Amana: The Community of True Inspiration (Iowa City, 1908), 177; Nordhoff, Communistic Societies, 40. For other statements about the colonists not overexerting themselves, see Davenport Daily Gazette, 29 June 1867; and Cedar Rapids Gazette, 1 October 1883 and 8 February 1905. Middle Amana residents recall that some weavers were outsiders, some of whom were well known to the children of the colony for distributing candy that they purchased with their wages. Johanna Kippenhan Reihman, personal conversation with the author, 30 June 2000.

35. Charles J. Kippenhan to the author, 3 July 2000; Crockett, The Woolen Industry of the Midwest, 62; Jacquelyn Dowd Hall et al., Like a Family: The Making of a Southern Cotton Mill World (Chapel Hill, NC, 1987), 56; Ely, "Amana," 663. That very few women worked in the factories is suggested by the inability of elderly residents of the Colonies today to recall the names of women who worked in the factories. Most suggest that women workers were a later innovation following the 1932 reorganization. Women do not appear to have been identified as factory workers on the Amana census rolls. Only the chance discovery of a list of mill employees at Main Amana from about 1885 substantiates the pres- 
Bertha Shambaugh, a leading observer of Amana, offered a romantic portrait contrasting the industrious female operatives of eastern textile mills with "the placid matron of the Amana mills in her austere costume" who "sets one to dreaming of the patient industry of our pilgrim foremothers." For Shambaugh, the women of the Amana mills were quaint and charming relics, not, as they were, in fact, workers in a competitive, industrialized factory. Shambaugh was unable to reconcile the presence of a factory in the middle of a community that she elsewhere characterized as a "garden." For her, the presence of "placid matrons," old-fashioned spinning wheels, "an occasional spray of blossoms on a loom frame and the humming of a psalm tune by an Elder" served to obscure the reality of the mill and, instead, cloaked it with the "garden village" aura that it directly challenged. Although very few women worked in the Amana woolen mills, those who did were not old, and likely were not particularly placid. Despite being given lighter tasks than men, and certainly lighter tasks than women outside the community, they were not "placid matrons," but in some cases fairly young women who gave years of service to the factory.

In addition to employing few women, the Amana Society's woolen mills differed in another crucial respect from other mills by not employing children. The youngest workers allowed in the mills were all at least 14 . The Society did, however, make use of the nimble hands and fingers of its youth in other ways. For many years, children, along with women, knitted stockings, mittens, and wristlets during manual training sessions at school. The Society marketed those goods along with its other woolen goods. Children also helped to maintain the Society's orchards and performed small tasks during the year. Still, the little opera-

ence of women as workers. That undated list of Main Amana woolen mill workers includes the names of three Amana women: Pauline Zscherny (18701945), Lina Schehl (1859-1935), and Ernstine Singwald (no dates available). The list had to be made prior to 1885 , when one of the male workers listed died. As a result, Zscherny was, at most, 15, and Schehl (who had the distinction of being the first child born in Main Amana) 26 at the time the list was compiled. No other list of female mill workers has been located. Main Amana Woolen Mill Workers List, ca. 1885, author's collection; Genealogy File, AHS.

36. Shambaugh, Amana: The Community of True Inspiration, 178, 180. 
tives who so often were injured, maimed, and otherwise suffered in the mills of the Northeast were not to be found in Amana. ${ }^{37}$

The average woolen mill worker was male and worked at a skilled position in the mill, year round. Like other members of the Society, mill workers typically began their work in their teens, sometime after they completed the eighth grade and their local Bruderrath assigned them to a job. Workers could expect to move from one job to another within the factory, although many remained weavers or dyers, for example, for their entire lives. When needed, mill workers assisted in harvests and other tasks. Some individuals apparently worked in the mills only during peak production periods, but otherwise performed other jobs within the community.

In 1884 Ludwig Huebner, a weaver, described the pattern of work in the Middle Amana factory, in this rare account written to his brother-in-law:

Early, 6:30 a.m. we go to eat in the [communal] kitchens. ... then I go to my job. ... At 11:30 a.m. we go eat again, and we have at home a 15-minute worship, after which we do whatever small tasks need doing, until 12:30 p.m., when we go back to school and work. At 3 p.m. we have a break, at which time we have a beer, the same as at the mid-morning break, except now because of the [Iowa] temperance law we have coffee instead. Evenings, at 6:15, the workday ends. At 7 p.m. we go to eat. At 8 p.m. there is a half hour prayer service. ${ }^{39}$

Huebner's description of a workday punctuated by coffee or liquor breaks and church services captures both the relaxed at-

37. Hall et al., Like a Family, 56-65; Nordhoff, Communistic Societies, 42. Manufacturing census records for the years 1880-1900 fail to note a single Amana woolen mill worker under the age of 16 .

38. William A. Hinds, American Communities and Cooperative Colonies, 312; Carl Metz, interview by Joan Sniezewski, 25 March 1982, typed transcript, Oral History Collection, AHS. Metz stated that he "worked [in the factory] mostly in the wintertime. See, in the summertime, we had to work out in the fields."

39. Ludwig Huebner to Ludwig Herrmann, Autumn 1884, trans. Catharine Guerra, folder 38, Genealogy Collection, AHS. The use of beer at both the morning and afternoon breaks is confirmed by an 1891 newspaper account of the Society, which also states that the practice had ended because the colonists scrupulously observed Iowa's prohibition laws. Cedar Rapids Evening Gazette, 12 August 1891. 
mosphere of the factories and the way they differed from similar mills in the outside world. The workday, as described by Bertha Shambaugh in 1908, lasted 91/2 hours (in contrast to workdays of up to 12 hours in factories in the outside world). After 1900, factory work hours could continue until later in the day because, by then, the factories were lit by electricity, likely the only buildings in the village so outfitted. ${ }^{40}$

If, as in the case during the summer when the fall orders were being filled, employees had to work overtime, they received extra compensation, either in credit at the village stores or in cash. Huebner noted that by "working overtime in the factory evenings 8 to 11 o'clock," he had been able to add to the small allowance the Society gave his family; he had "made close to $\$ 50$, and bought a sewing machine and furniture." The credit offered to mill workers as compensation for extra work was an exception for the Society, perhaps reflecting the mills' status as income-producing enterprises requiring the services of its workers to fulfill purchase orders. The incentive thus suggests a lack of pure communal effort in the Amana factories. Just like workers in the outside world, Amana mill operatives gave extra effort if given an incentive. ${ }^{41}$

Conditions within the mills were far from bucolic. During summer months, the temperature inside the mills could be much more unpleasant than outside because of humidity created by the washing and dying processes and the heat generated by the looms. In winter, the mills were heated by steam heat, and the same conditions that rendered them unpleasant in summer

40. Shambaugh, Amana: The Community of True Inspiration, 179. Shambaugh noted that the hours were typically "the usual Amana hours of from 7:00 to 11:00 A.M. and from 12:30 to 6:00 P.M. But during the summer months when the orders for the fall trade are being filled, the mills run from 4:30 in the morning to $6: 00$ in the afternoon; or from 7:00 in the morning to 11:00 at night." An undated placard preserved in the collections of the Amana Heritage Society lists winter woolen mill hours as 7-11 a.m. and 12:30-6 p.m, except on Saturday when afternoon hours were 12:30-4 p.m. It is likely, based on the evidence that placards of this type were produced, that Amana mill hours varied through the years, although they appear to have been fairly consistent. Amana Society, "Winter Periode Arbeits Stunden in den Wollen Fabricken," Amana Society Woolen Mill Collection, folder 8, box 1, AHS; Shambaugh, "Some of the Economic and Industrial Phases," 506.

41. Ludwig Huebner to Ludwig Herrmann, Autumn 1884. 


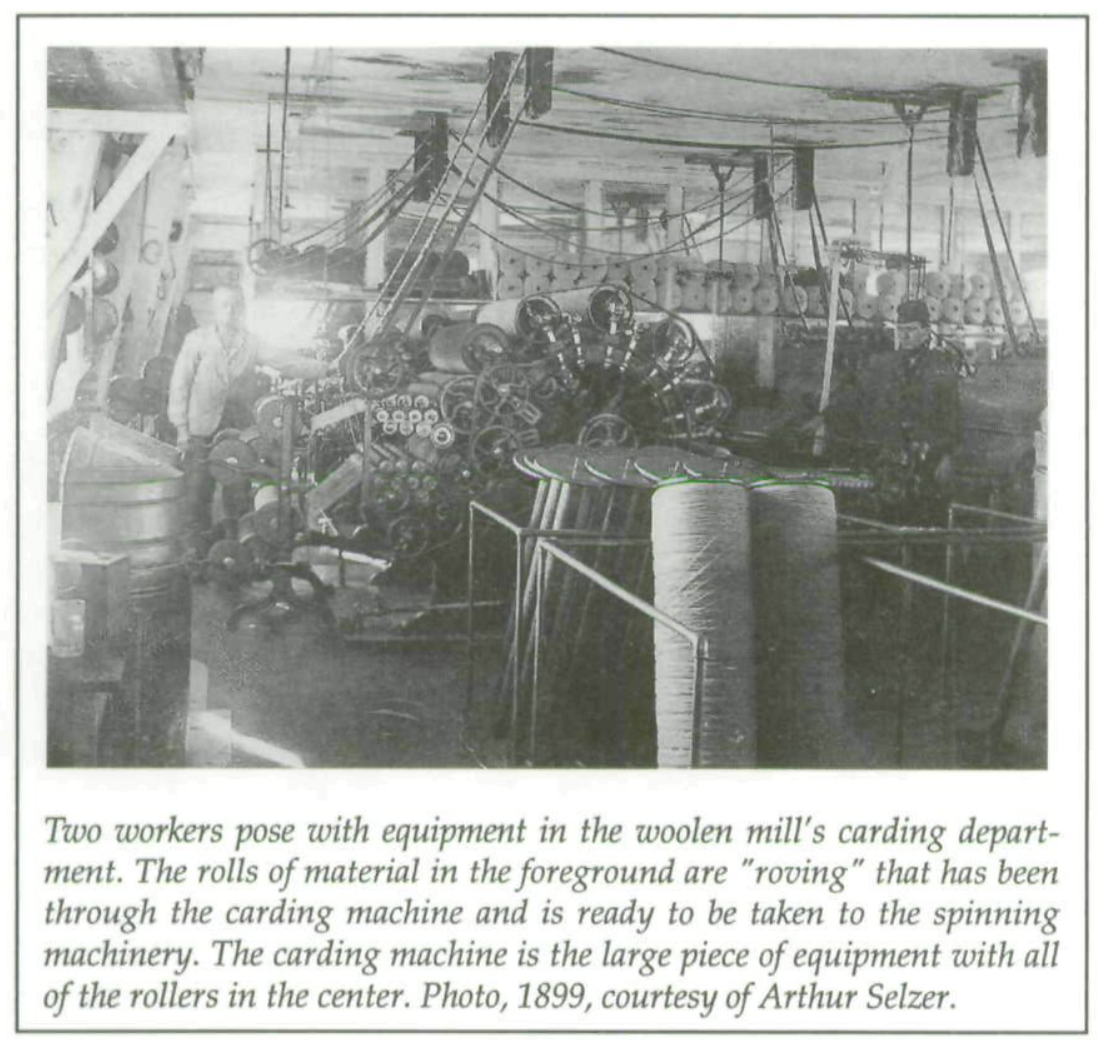

served to make them bearable in winter. Large windows illuminated workspaces and provided ventilation in the summer. Opening the windows spread the thundering sound of the looms throughout the village. The noise in the mills suggests that Bertha Shambaugh's remark about pious mill workers offering hymns while at work was an exaggeration. ${ }^{42}$

The mills and mill equipment could be dangerous for workers. In the weaving department, for example, iron-tipped shuttles often flew off the end of the looms as they shot across, leaving dents in the soft brick walls of the factory. Shuttles often struck mill operatives, although never fatally. One longtime Amana weaver recalls the time a shuttle flew off a loom, through a

42. Johanna Reihmann Leichsenring, personal conversation with Darlene Leichsenring Fratzke, 22 March 2001, copy of notes in author's collection; Shambaugh, Amana: The Community of True Inspiration, 180. 
nearby window, and landed in the middle of the road outside, several feet away. On another occasion, a shuttle struck this man on the chin. Such a dangerous and noisy atmosphere contrasts sharply with the serenity portrayed by Shambaugh, Wallace, Shaw, and others. The Society did, however, care for injured Amana wool workers, whether they were able to return to their duties or not. Unlike their outside counterparts, therefore, Amana workers did not have to worry about what would become of them or their families in the event of a debilitating injury. ${ }^{43}$

Despite the danger inherent in the use of power machinery, in the period from 1838 to 1942 the Society recorded only two deaths directly attributable to operations in the mills. The first occurred in 1877 when a young boy climbed through a window in the Middle Amana mill and was struck and killed by a belt. The second incident, also at Middle Amana, occurred in 1925 when a mill employee fell down an elevator shaft to his death. In less directly related accidents, a third man was killed while installing mill wheels at Middle Amana, and at least three young people, one only four years old, drowned in the millrace. None of these latter incidents, however, was directly tied to millwork, and none compares with the horrendous accidents reported in textile mills in the outside world. Longtime Amana residents are unable to recall individuals who received serious injuries from the mills, although some injuries, such as hearing loss, often not attributed to the mills, were likely caused by conditions there. Carl Neubauer, who worked in the dye house during the early 1900s, reported burning his overalls on one occasion while carrying a container of acid. Such minor accidents were likely common, but did not result in serious injury. ${ }^{44}$

43. Charles Hoehnle, personal conversation with the author, 22 April 2001. Hoehnle's father, Jacob Hoehnle, worked as a weaver in the mill for more than forty years.

44. For an account of these accidents, see Gottlieb Scheuner, Inspirations Historie, 1877-1883 (Amana, 1916); Peter Stuck and August Koch, "Inspirations Historie, 1925," unpublished manuscript, AHS; Neubauer, Diary, 3 September 1910. For accidents in southern mills, see Hall et al., Like a Family, 82-86. The three boys who drowned in the millrace were Heinrich Murbach, Heinrich Wolf, and Wilhelm Goerler. Murbach and Wolf drowned while trying to cross the millrace in a small boat, and four-year-old Goerler fell into the canal. All three boys died in 1876. 


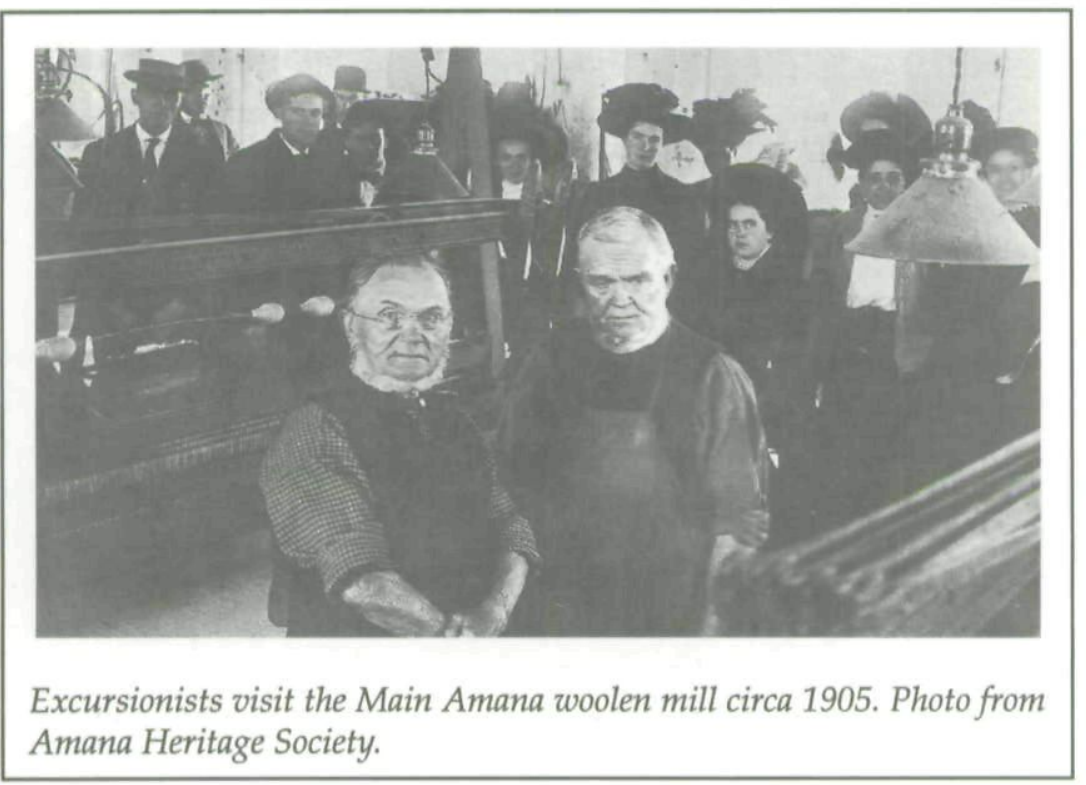

What is most remarkable about the lack of serious accidents in the mills is that apparently the Society gave little attention to shop safety. After the turn of the century, state safety inspectors visited the mills and, on at least one occasion, ordered the Society to make some alterations to its machinery. Still, safety requirements were not stringent, and the Society even allowed visitors to wander around the factory at will. At least one visitor was struck by an errant shuttle but not injured. In later years, the Society required visitors to sign a short printed form, absolving it of responsibility for injuries. ${ }^{45}$

Perhaps the relatively low number of accidents in the mills was due to the relaxed atmosphere. As with other phases of Amana work, observers noted that woolen mill workers did not overexert themselves. In various parts of the mills, areas were set aside for the workers to eat their mid-morning and midafternoon "lunches" - coffee breaks supplied by the kitchen

45. John Heinemann to A. L. Urick, Commissioner of Labor, 25 August 1913, folder 2, Heinemann Family Papers, AHS; Johanna Leichsenring, personal conversation with Darlene Leichsenring Fratzke; Cedar Rapids Gazette, 12 September 1985; "Visitor Permit," Amana Society Print Shop, Scrapbook \#3, 71, AHS. 
houses. Carl Neubauer made virtually daily notations of the materials he had dyed in the morning, but almost as often noted going fishing in the afternoon, playing cards at night, and, in one instance, observing one of his coworkers spend all day sleeping off a nasty hangover in a pile of wool. ${ }^{46}$

NOT ALL OF THE WORKERS connected with the textile industry in Amana worked in the mills themselves. Several auxiliary crafts supported the mills. Both the Amana and Middle Amana facilities, for example, had their own machine shops that made replacement parts and metal castings for use in the mills. Other workers either directly or indirectly tied to the mills included shepherds, salesmen, warehouse workers, and the employees of the Society's print shop, who produced advertising material for the mills' products.

Among the most significant workers connected with the mills, but not directly employed by them, were those who supplied the mills with raw wool. Farm laborers maintained the Society's large flocks of Shropshire sheep, averaging a total of 3,000 sheep. The flocks were located in the villages of South, West, and East Amana, but principally around East Amana, where the land was hilly and unsuited for most crop production, and where the Society quartered 1,350 of its 4,090 sheep in 1892. Local children eagerly anticipated the exciting times when the large East Amana flocks were herded through the village of Main Amana as they were moved to nearby pastures. ${ }^{7}$

The Society purchased additional wool from outside the community. In the 1860s and 1870s, when the Iowa wool industry was at its peak, the Society purchased a great deal of wool from neighboring farmers. As Iowa farmers shifted from grazing to crop production, the Society had to look farther afield for its wool. As late as the 1910s the Society dispatched wool buyers to the southern portion of the state, where the Iowa sheep in-

46. Neubauer, Diary, 3 November 1910.

47. Assessors Report, Amana Township, 1892, AHS; Elizabeth Werner Christen, interview with Kirk Setzer, 1982, typed transcript, Amana Oral History Collection, AHS. On sheep raising in Amana, see Marcelee Berger, "Sheep Raising," unpublished paper, folder 1960, Amana High School Collection, AHS. After 1940 , the Society no longer raised sheep for use by the woolen mill. 


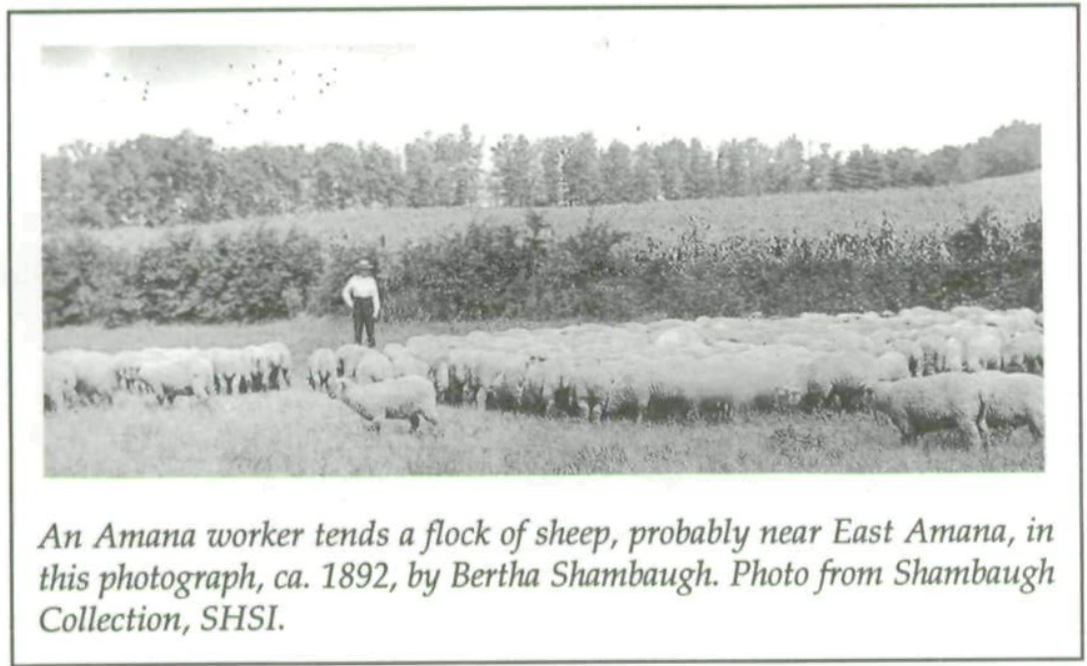

industry, never large, was centered. The Society also purchased some wool from Chicago dealers. ${ }^{48}$

Other workers who made an important, if indirect, contribution to the Amana textile industry were the men employed on the dredge boat. Known locally as Das Grosse Boot (the big boat), the Amana dredge first began operation during the construction of the millrace in 1867. In 1921 the Society realized that by running mill turbines on Sunday, silt would not settle on the bottom of the canal. This violation of the Sabbath was considered reasonable, given the savings in men, money, and time, and the dredge boat was scrapped. ${ }^{49}$

48. Earle D. Ross, Iowa Agriculture: An Historical Survey (Iowa City, 1951), 5657; Richard H. Roberts, "Report to Dr. Benj. F. Shambaugh upon Field Research in the Amana Colonies in 1934-35," unpublished paper, Amana Society Collection, State Historical Society of Iowa, Iowa City, 69; Nordhoff, Communistic Societies, 42 . Nordhoff quoted a local farmer as saying that the Society always paid for its wool in cash, was known for its integrity and plain dealing, and would never deal again with anybody who had wronged them in a sale. Carl Neubauer recorded several trips by his father to purchase wool in Mahaska County and other places. Neubauer, Diary, 11 May and 19 July 1910.

49. The boat, with a crew of three plus a captain, slowly dredged the entire length of the seven-mile-long canal each summer. The eight bridges crossing the canal were disassembled to allow the boat to pass, a process that took a full day. As they traveled down the canal, the boatmen ate at the kitchen houses in whatever village they were nearest; according to a local joke, the canal was 


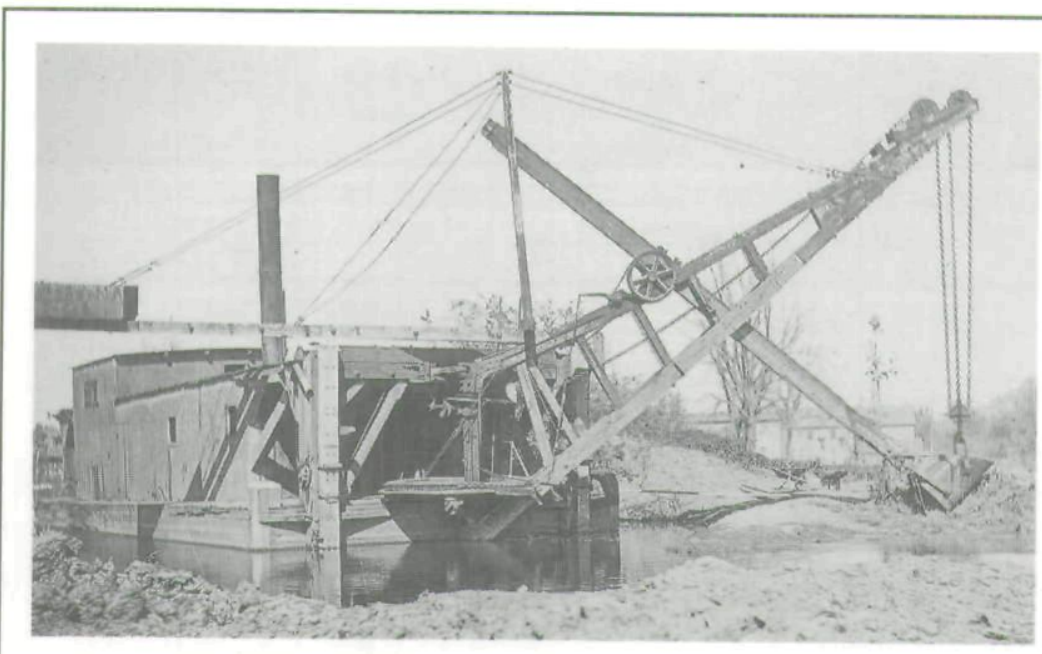

The dredge boat clears the millrace, probably near Main Amana. Workers pounded the two large posts protruding in the front of the bow into the soft mud of the millrace to anchor the boat. When local children heard the sounds of the engine and chains, they would come down to the millrace to watch. Photo courtesy of Arthur Selzer.

A tiny but important group of auxiliary workers connected with the mills were the Society members who served as salesmen and who regularly traveled around the country selling and taking orders for Amana goods. Each salesman carried sample books containing small examples of the Society's calico patterns and woolen products. The salesmen represented an elite in the Amana social structure. Most of them worked in the Amana village stores when not on the road, and most were members of the Society's leading families. Indeed, several members of the Board of Trustees were often on the road during the summer months selling Amana textiles and other wares. Unlike many Society members, they could speak English fluently, were afforded a larger allowance by the Society to dress appropriately for their calling, and were able to see the outside world, report-

deepest at Middle Amana because the crew enjoyed the food at those kitchens the most! Ralph H. Ruedy, "Das Grosse Boot," unpublished paper, Amana School Collection, AHS; Terry Trimpe, "The Building of the Amana Mill Canal," unpublished paper, 1965, folder 47, Amana School Collection, AHS. 
ing back to the Society on current trends in fashion and woolen fabric. Over the years, strong relationships developed between the Society and retailers such as Macy's of New York, Marshall Field's of Chicago, and the Wanamaker Department Store in Pittsburgh, enabling the Society to sell its products by reputation to an established clientele that marketed them for decades. ${ }^{50}$

John Heinemann, a veteran Amana salesman, annually mailed form letters, printed at the Society print shop, to his regular customers announcing his upcoming visits. These letters included glowing references to his wares, but, like almost all of the promotional material produced on behalf of the woolen mills, made no reference to the communal or religious aspects of the Society. Instead, advertising material emphasized the quality and reputation of Amana products as well as their low cost. The average consumer, without any previous knowledge of the community, would not have perceived the Amana mills as different than those producing competing merchandise. The nature of its advertising indicates that the Society did not intend to use its goods to proselytize or gain converts. Or it may simply have wished to avoid stirring up biases against itself as a sectarian religious group. Amana advertising, typical of the era, was simple and direct. Society salesmen who proclaimed in their letters that "perfection is a rare thing in this world of ours; but we constantly aim to reach it," and that "we have the best line on the market" were echoing hyperbole typical of the "traveling fraternity" at the turn of the century."

50. Advertising Letter, 1929, Amana Society Print Shop Scrapbook, vol. 5, AHS; Charles J. Kippenhan to the author, 30 July 2000. Among the Amana salesmen were Society trustees John Heinemann, Adolph Heinemann, William F. Moershel, Adolph Goepp, Abraham Noé, and Carl Ratzel.

51. John Heinemann, advertising letter, 10 May 1897, Amana Society Print Shop Scrapbook \#1, AHS; Charles Moershel, advertising letter, 1 June 1895, ibid. Other examples of advertising materials can be found in the Amana Society Print Shop Scrapbooks, AHS. The letters often display bizarre turns of phrase, suggesting that the authors of the Society's advertising materials were not entirely comfortable with the English language. For example, the only letter located that referred to the communal nature of the Society states: "In this connection we want to advise our Friends that our Society was organized and founded with the principle and determination to live not only for this, but for many generations to come, to pursue their benevolent cooperative vocation, for the good of themselves and mankind in general." Adolph Goepp, advertising letter, 31 March 1905, Amana Society Print Shop Scrapbook \#1, AHS. 
Another auxiliary business attached to the mills was the wholesale warehouse at Homestead. When the Society began producing textiles in Iowa, the nearest railroad station was in the village of Homestead. Because of their need for a shipping point, and wishing to limit contact between members and outsiders as well as to increase their land holdings, the Society bought the entire village in 1861 and erected two large warehouses behind the village's general store where all of the Society's textiles were stored before they were shipped to customers. As with the managers of other textile-related businesses, the manager of the Wholesale Department was also a church trustee, and, for many years, one of the managers was the vice president of the Society. ${ }^{52}$

The final group of individuals intimately connected with the mills was the Society's Board of Trustees. Throughout the communal period, the trustees rendered many decisions important to the growth, maintenance, and development of the Society's textile industry. What is remarkable, however, is the degree to which the Society's officers were tied to its textile production on a personal level and, more astounding, how many of them belonged to the single, extended family most connected with that production: the Winzenrieds. Of the 19 men who served as presidents, vice presidents, secretaries, and treasurers of the Amana Society between 1859 and 1932, all but two were related to the Winzenried family by blood or marriage. The managers of both the Main Amana and Middle Amana Woolen Mills were, with one exception, Winzenrieds or their descendants. ${ }^{53}$

52. In the basement of one of the wholesale buildings a carpenter constructed the huge crates needed to ship items. Upstairs, clerks kept track of orders in the office. An elevator provided access to the second floor of these cavernous buildings.

53. The names of the officers of the Amana Society and their dates of service are in the minutes of the Board of Trustees, held in the archives of Amana Society, Inc., Amana. For biographical data on individual officers, see the cemetery record file of the Amana Heritage Society. That file, begun by Jonathan Andelson as part of his landmark dissertation work on the Society, contains individual cards for each individual buried in the Amana cemeteries, with pertinent biographical material summarized from the obituaries written on each member in the community chronicle, the Inspirations Historie. 
Amana scholars have long acknowledged that an "aristocracy of elders" governed the community, but the degree to which the upper echelons of that aristocracy concentrated in a single family has never been noted previously. The Winzenried family drew its position from the important role its patriarch, Carl Winzenried, one of the founders of the Society's textile industry, took in community affairs. From 1846 until his death forty years later, Winzenried was the Society's principal financial authority, a man respected not only for his business acumen but for his spirituality as well. To a large degree, he was the actual head of the Amana Society. ${ }^{54}$ Clearly, power in the Society was predicated less on one's religious piety than on one's connection to the Society's most significant form of revenue: the woolen mills.

For residents of the Amana villages, the woolen mills were a constant presence. The three smokestacks that marked the mills in Main Amana and Middle Amana were landmarks that could be seen from a considerable distance. On very still days, or when the wind blew in the right direction, the factories filled the villages with noise. Women almost exclusively wore Societyproduced calico, and blue dye from the mills, thrown into tubs of white wash, was likely the source of the distinctive "Amana blue" that covered the walls of every room in the seven communities. The women of the community sewed quilts filled with carded wool from the factories in rooms where the floors were covered by rag rugs woven from mill ends and rag material dyed at the factories. Representatives from the various kitchen houses trooped to the dye houses in Main Amana and Middle Amana to acquire the dye for coloring Easter eggs. And kitchen workers in those two villages used special steam-heated rooms in the factory buildings to dry fruit and vegetables for use during the winter. Even the villages in which a factory was not present felt the influence of the textile industry. The village of Home-

54. Even during the life of Christian Metz, Winzenried served as president of the Society. Although the Society was nominally under the leadership of Barbara Landmann after Metz's death, Winzenried led it in actuality. He provided a bridge that served to mitigate the loss of charismatic authority in the community, and he, more than any other single individual, helped to establish the economic basis upon which the Society continued for 89 years. 
stead, for example, maintained the large warehouse where textile goods were stored and the depot from which they were shipped. The villages of East, South, and West Amana maintained huge herds of sheep whose wool was used by the mills..$^{55}$

THE SYSTEM of woolen production established in the early days of the Amana settlement continued, as technology and fashions changed, until the early years of the twentieth century. One of the first major changes began with the advent of World War I. Although the Society was pacifistic, it applied for, and received, large government contracts for cloth. Government contracts meant the temporary cessation of commercial production and the presence of government inspectors in the mills. ${ }^{56}$

During the war, local outsiders questioned the loyalty of the German-speaking and pacifistic Society. The editor of the $\mathrm{Ma}$ rengo Sentinel suggested that the only remedy for the Society's "Kaiserite tendencies" would be to have the courts act against the "Amana slackers" and sweep the "whole unwholesome mass into the Iowa river with a stub broom" or, at least, "knock the darn colony higher than the scaffold of Hamen." The Society took particular pains to demonstrate its loyalty by touting the wartime production of the mills, both in publications and through public tours of the facilities. A large contingent of soldiers training at Iowa City visited the Amana villages in 1918 and toured the mills. Not only did the Society offer hospitality to the soldiers, but it also printed and distributed a booklet,

55. Johanna Reihmann Leichsenring, personal conversation with Darlene Leichsenring Fratzke; Charles J. Kippenhan to the author, 30 July 2000; Johanna Kippenhan Reihman, personal conversation with the author, 30 June 2000; Lina Roth Unglenk, personal conversation with the author, 4 September 2000. Main Amana dye house worker Carl Neubauer always recorded the visits of the appointed women from the various kitchen houses to obtain dye from him for Easter eggs. Neubauer, Diary, 26 March 1912. That practice continued beyond the reorganization of the Amana Society in 1932. As late as the early 1980s, local women still visited the dye house in order to obtain dye for their Easter eggs. Charles Hoehnle, personal conversation with the author, 22 April 2001.

56 . The huge labor demands necessitated by the government contracts led the Society to employ some members below the government's age limit of 17 in the factory. These young people left the factory on the days of government inspections. Carl Metz, interview by Joan Sniezewki, 25 March 1982, typed transcript, Oral History Collection, AHS. 
published in area newspapers, containing accounts of the visit. According to one journalist, the mills turned out 35,000 blankets during the war. He also commented that it was "an industrial surprise to find in the heart of what looks so intensely rural a fully equipped woolen mill" capable of such production in so short a time. Once the war was over, the Society sent a form letter to regular customers giving thanks for peace and noting that regular production would be resumed shortly. ${ }^{57}$

Five years after the end of the war, regular production was again disrupted. On August 11, 1923, a fire, presumably the result of a dust explosion in the flour mills located across the millrace from the woolen mill in Main Amana, destroyed the major part of both facilities. The woolen mills, and the Amana Society in general, were never the same after that date. Ten buildings in the woolen mill complex burned despite the heroic efforts of residents. An engineer managed to keep the mill's enormous steam engine running in order to provide water pressure for the Society's antiquated fire-fighting equipment until he was forced to flee when the roof of the building collapsed. Fire equipment brought to the scene from the neighboring communities of Iowa City (whose mayor, Emma Harvat, came along on the fire engine), Marengo, and Oxford, aided residents in fighting the blaze. The heat was so intense that some firefighters fainted. The fire could be seen from South Amana as "funnels of flame rose a hundred feet in the air consuming oxygen in great gulps that boomed like thunderclaps." Residents formed long lines to pass goods out of the mill buildings to safety. In their panic, workers cut the warps out of the looms in the weaving building and threw equipment out of upstairs windows, breaking much of it in the process. When the flames subsided, only the weaving building and a few ancillary structures remained. The loss was estimated at between $\$ 250,000$ and $\$ 500,000$. The mill was uninsured. ${ }^{58}$

57. Marengo Sentinel, 26 February and 5 March 1918; Iowa City Daily Press, 7 August 1918; Cedar Rapids Republican, 12 August 1919; Advertising Letter, 25 December 1918, Amana Print Shop Scrapbook \#3, AHS, 101.

58. Al Kellenberger, interview, 15 March 1982, typed transcript, Oral History Collection, AHS; Emilie Hoppe, "One Afternoon in 1923 the Mills Went Up in Smoke," Wilkommen, Winter 1999; Peter Stuck, "Notes on Woolen \& Flour Mill Fire 1923," unpublished journal, author's collection; Adolph Heinze, interview by Barbara Hoehnle, typed transcript, Oral History Collection, AHS; Charles 


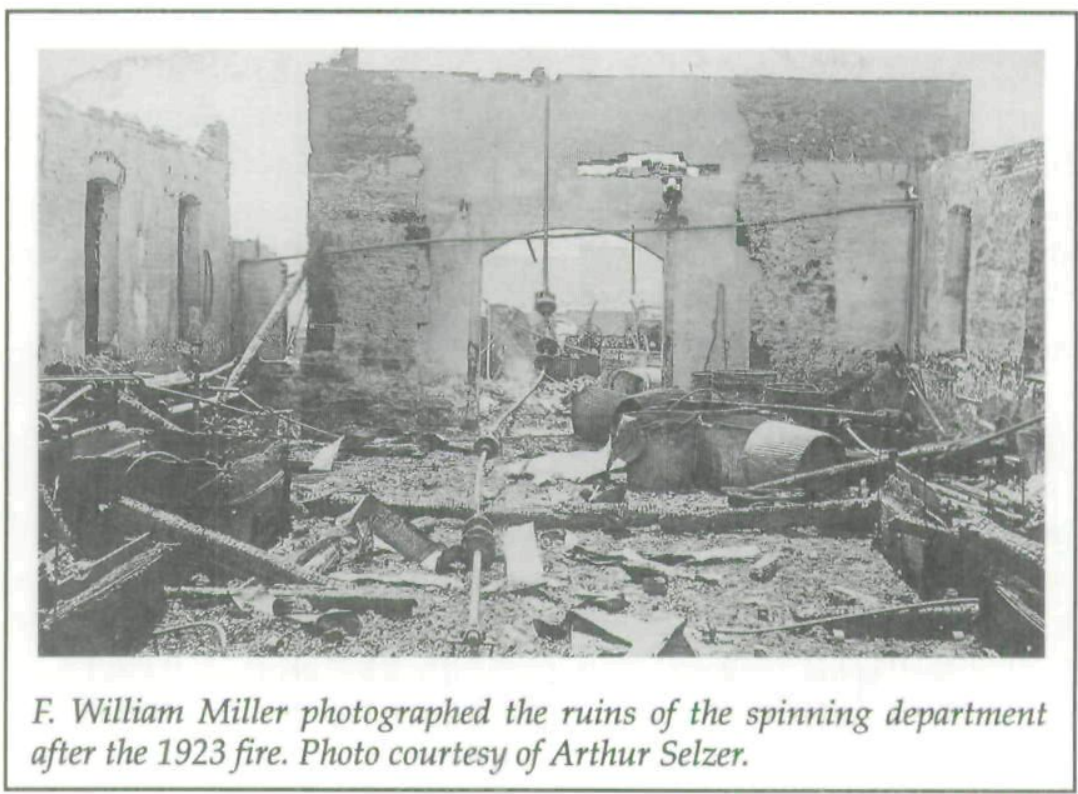

Newspapers across eastern Iowa reported sympathetically about the fire. The Davenport Democrat voiced the hope that the "effects [of the fire] will soon be wiped out... [and] the colonies [will] be pursuing the even tenor of their ways as heretofore." Society official William Moershel told the press that there were some bright spots in this almost unmitigated disaster. The weaving building, containing the most expensive of the mill's equipment, the village of Main Amana itself, the firefighters,

Hoehnle, personal conversation with the author, 22 April 2001. Immediately after the fire the county attorney, J. P. Gaffney, suggested that the fire was the result of arson. Marengo Republican, 15 August 1923. The state fire marshal investigated, but no one was charged with setting the blaze. Society leaders maintained to the local press that it was the result of a dust explosion. J. A. Tracy, State Fire Marshal, to William F. Moershel, 31 August 1923, author's collection. The day after the fire, the Society held special church services in each village at which the elders read Barbara Landmann's testimony regarding the first fire at the Middle Amana Woolen Mill, and members sang the hymn "How Dreadful is the Lord." The service ended with the hymn "Arise My Spirits," after which residents of all seven villages converged on the ruins to begin the process of cleaning up, as carloads bearing hundreds of outsiders drove slowly by the site to gawk. Georg Heinemann, Inspirations Historie, 1915-1923 (Amana, 1924). 
and Society members were all unharmed. At the time, the warehouse at Homestead was filled almost to capacity, allowing the Society to fulfill some of its regular orders. Furthermore, although all of the Society's raw wool was destroyed, it had only a small supply on hand, waiting for a drop in prices to buy more. Finally, the Middle Amana mill was still in operation and, by operating at increased levels, helped the Society meet its outstanding orders. ${ }^{59}$

There was no doubt among the Society leadership that the mill would be rebuilt. Soon after the fire, Peter Zimmermann, the mill's manager, sketched a plan for rebuilding the factory, and construction began immediately, using Society labor and materials. On February 7, 1924, just six months after the fire, the weavers worked the first yarn spun in the rebuilt buildings through their looms. ${ }^{60}$

But the loss caused by the fire, coming on the heels of a general decline in revenue from the mills and the impact of the agricultural depression of the 1920s, was staggering, and contributed to the Society's generally worsening financial standing. The mills that had provided financial security for the Society for more than 85 years, failed it at the time when they were needed most. In 1922, before the fire, the mills had showed a profit of $\$ 80,000$. In 1923 , the year of the fire, the Society not only faced the loss brought by that disaster, but also a severe decline in the national woolen market. After years of declining profits, the mills hit bottom in 1931, earning only $\$ 24,000 .{ }^{61}$

By April 1931, the financial pressures on the woolen milland on the Society as a whole-had become severe. Internal pressures forced Society leaders to seriously consider abandoning the communal system. Members were tired of the selfsacrifice required for communal living. Beginning in April 1931, the Society initiated a process in which an elected committee devised a plan to reorganize as a profit-sharing corporation,

59. Cedar Rapids Republican, 12 August 1923; Davenport Democrat, 13 August 1923.

60. Georg Heinemann, Inspirations Historie, 1915-1923; Peter Zimmermann, "Preliminary Amana Factory Plans," 16 August 1923, folder 2, Heinemann Family Papers, AHS; Peter Stuck, "Notes on Woolen and Flour Mill Fire 1923," 7 February 1924, folder 12, box 4, Amana Woolen Mill Collection, AHS.

61. Andelson, "Communalism and Change," 360, 362. 


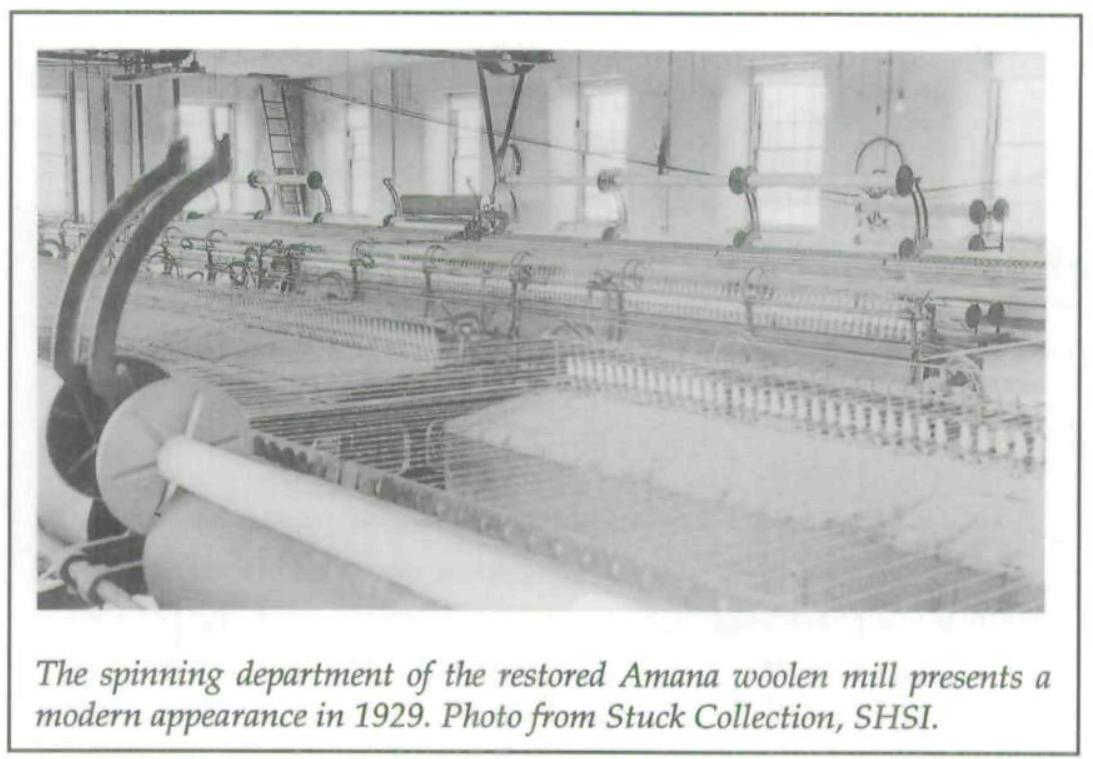

which the membership then approved. The new system formally went into effect on June 1,1932. ${ }^{2}$

Under the new system, Society members became employees who received hourly wages and could be hired and fired from their positions without the influence of religious authority. The end of the communal system also meant the closing of the communal kitchens, where most Amana women worked. Although many women became homemakers following the reorganization, others, particularly young unmarried women, began to work in the woolen mills. The chance to work, even on a parttime basis, was enticing to many women who might otherwise have felt the void left by the closing of the communal kitchens. Although some women continued their employment, many worked only until they married. The presence of women in the mills appears to have angered male employees, some of whom petitioned the Amana Society Board of Directors to fire women who were taking jobs away from men who, they felt, were the main supporters of their families. At the time of the petition, the

62. For the reorganization of the Amana Society, see Peter Hoehnle, "Community in Transition: Amana's Great Change, 1931-1933," Annals of Iowa 60 (2001), $1-34$. 
management had cut mill hours. During the six-month transition period from the communal system, between June 1932 and January 1933, all Amana Society employees worked for ten cents per hour. Under those circumstances, given Amana's generally patriarchal nature, the male mill workers' protest is comprehensible. $^{63}$

Following the reorganization, the Amana Society obtained the services of an outside business manager, Arthur Barlow, to manage its affairs. Barlow instituted changes in the Society's financial practices, such as implementing double entry bookkeeping. Barlow also altered the fundamental management of the woolen mills by naming Peter Zimmermann the overall superintendent for both the Main Amana and Middle Amana facilities, which had previously been managed independently. When Zimmermann suffered a fatal heart attack on February 26,1933 , Barlow rushed to fill the void by assuming direct control of the mills. Zimmermann, who had been the manager since 1903, had never delegated authority. Thus, when Barlow arrived on the scene, he found that the only person with a working knowledge of each department and the mill office was Zimmermann's 21-year-old secretary, Helene Schmieder. With her assistance, Barlow indirectly managed the mills until an outside manager could be hired. By insisting on hiring an outside manager, Barlow effectively ended a century of managerial control of the mills by the Moershel and Winzenried families. The new outside manager, Clarence Gieb, was employed for

63. Amana Society Board of Directors, Minutes, 21 December 1932, Amana Society Archives, Amana Society Main Office, Amana. Such protests by male workers were common across the United States during the Great Depression. Although the Society raised wages for mill workers after January 1933, they were still comparatively low. Under the New Deal, the Society, as a manufacturer, participated in the National Recovery Administration. As a participant, the Society had to observe NRA regulations regarding minimum wages, hours, and child labor. Unable in its existing condition to raise employees' salaries to the minimum required, the Society successfully appealed for an exemption, based on the fact that its workers received benefits, such as free health care, as a condition of their status as members of the Society. Roberts, "Report to Dr. Benj. F. Shambaugh," 107-8. Apparently, the Society did not receive a similar exclusion during World War II when it produced fabric for the U.S. government and for the Soviet Union. The government required that workers be paid a minimum wage. Cedar Rapids Gazette, 1 September 1985. 
only a short time, with the understanding that he would streamline mill operations. ${ }^{64}$

One of the major concerns for the Society at that time was the mill at Middle Amana. Employees at the Middle Amana facility, unlike those at Main Amana, were openly hostile to the new outside managers. As a result, one manager stopped going to the Middle Amana facility completely. Inefficiency was rampant at Middle Amana, where outside observers reported inattentive weavers, and the Society's business manager complained of "the lack of co-operation and improper spirit." To make matters worse, the Middle Amana facility, unlike the Main Amana mill, which was rebuilt and reequipped following the 1923 fire, was outmoded. Managerial problems at the Middle Amana facility also concerned Society leaders. The appointment of Adolph Heinze as manager in 1934 alleviated those problems. Heinze, then only 22 years old but already a careful student of the textile industry, not only managed the mill but also introduced innovative designs, such as a two-tone blanket and ribbon bindings. He continued to play a leading role in the Amana textile industry through the 1970 s. ${ }^{65}$

During the later 1930s the mills began to recover from the effects of their downturn during the 1920s. Blanket sales rose from 5,092 in 1932 to 22,163 in 1933. By 1934, both facilities were running on double shifts. The debate over streamlining mill production continued, however. Finally, the facilities were combined, and Middle Amana workers began commuting the $1 \frac{1}{2}$ miles, on foot or in automobiles purchased after the reorganization, to Main Amana. The catalyst for abandoning the Middle Amana mill was the Amana Society's acquisition in 1936 of the re-

64. Williamsburg Journal-Tribune, 2 March 1933. Zimmermann had told Schmieder to learn all the processes of the mill as part of her duties as his assistant. Not only did that knowledge make her indispensable to Barlow following Zimmermann's death, but the inability of some of the older mill foremen to speak any English meant that Schmieder often had to translate for Barlow during staff meetings. In later years, Schmieder became one of the managers of the mill and the first woman elected to serve on the Amana Society Board of Directors. Helene Schmieder Rind, interview with Emilie Hoppe, 19 January 1982, typed transcript, Oral History Collection, AHS.

65. Roberts, "Report to Dr. Benj. F. Shambaugh," 76-78; Amana Society Bulletin, 2 August 1934. 


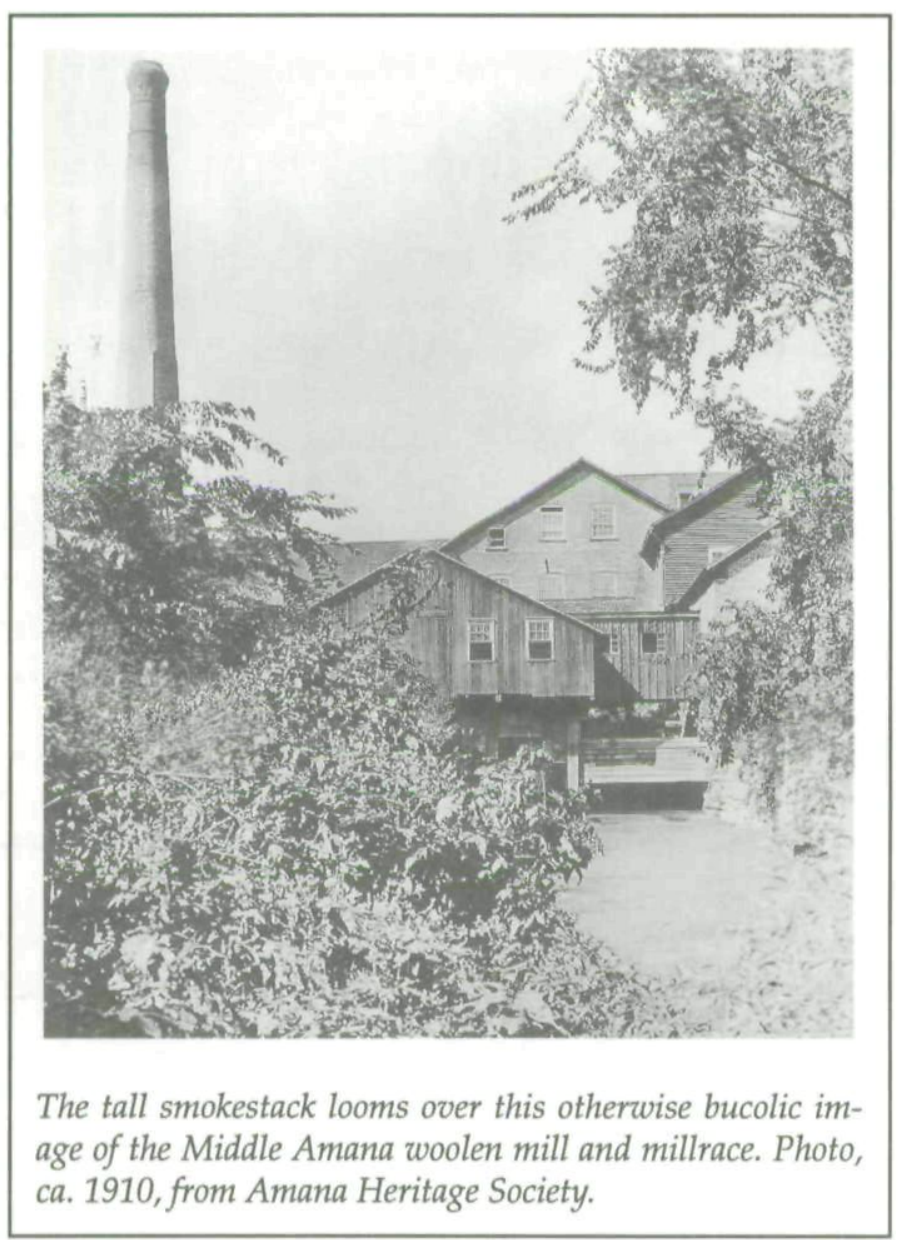

frigeration manufacturing business begun by one of its members, George Foerstner. Following a fire at its previous location, the refrigeration company began to move into an unused part of the Middle Amana facility. The mill merger was completed by $1942 .{ }^{66}$

66. Andelson, "Communalism and Change," 379; Roberts, "Report to Dr. Benj. F. Shambaugh," 81-82; Adolph Heinze, interview by Barbara Hoehnle, 17 June 1982, typed transcript, Oral History Collection, AHS; Amana Society Bulletin, 18 October 1934. The mills began working on shifts as early as 1933, according to one longtime employee. Cedar Rapids Gazette, 1 September 1985. Today, Amana Refrigeration employs more than 3,000 people in a modern facility built 
Not only did the management and product line of the mills change after the reorganization, but so did the method of marketing woolen products. Previously, the Society sold woolen goods (aside from those sold wholesale by its salesmen) either directly from the finishing department at the mills or in the Amana village stores. In 1934 the Society opened a separate retail facility at the Main Amana mill, shifting all local sales to the new facility. At the same time, the Society closed the wholesale department at Homestead and began to warehouse all of its finished goods at the mill in Main Amana. Finally, although the Society continued to send its own members out as salesmen, it also began to market goods through wholesale jobbers in the East. ${ }^{67}$

In the coming decades, the Amana woolen mill continued to change and develop in response to trends in the textile industry. The mill employed roughly 150 people as it had under the communal system, and it continued to provide an important source of income for the reorganized Amana Society. By World War II, the Amana woolen mill was the only remaining woolen mill in the state of Iowa. Today, the mill is a shadow of its former self, as foreign competition forced it to drastically reduce its work force and production capabilities in 1985. Housed in the renovated weaving building at Main Amana, the mill continues to produce a limited number of blankets, loungers, and other specialized articles that are sold at the adjacent sales room, along with the products of other mills. ${ }^{68}$

FOR ALMOST A CENTURY, the woolen industry of the Amana Society provided an important economic support for the maintenance of the Community of True Inspiration. The mills supplied the economic capital that made communalism practical.

around the original Middle Amana woolen mill buildings. The exact date on which the merger of the two mills was completed is unknown. I have used the first date on which the facility was referred to as the refrigeration factory instead of the woolen mill as the approximate date. Amana Society Bulletin, April 1942. Although the Middle Amana woolen mill was mostly destroyed by a 1943 fire, the walls and its distinctive smokestack remain.

67. John Reihmann, interview with Carol Zuber, 12 May 1982, typed transcript, Oral History Collection, AHS. Reihmann was the first, and later longtime, manager of the sales room.

68. Cedar Rapids Gazette, 14 August 1985. 
Ironically, one of the longest-lived communal societies in the United States survived, in large part, because of the highly capitalistic activity of its woolen mills. The woolen mills permeated much of Amana life, from providing employment for hundreds of its members to producing the fabric in which Society members dressed. The fundamental connection between the mills and the Amana Society is reflected in the fact that the leaders and managers of the mills and the members of the Board of Trustees were one and the same. That fact also highlights the degree of nepotism exercised in Amana, as generations of the same extended family maintained control of the community. Quite by accident, the Amana Society mills produced an idealized work environment in which injuries were rare and work was unrushed, yet performed with great skill-a goal that many utopian reformers failed to achieve. The Amana mills, with their smokestacks billowing forth great black clouds of smoke, stood in a community in which every house was covered with climbing vines and every spare foot of ground was cultivated with flowers and vegetables. The Amana mills were, almost literally, "machines in the garden." They were the grimy, noisy environments that made possible the bucolic peace around them. The shuttles that shot back and forth across the loom frames wove not only cloth but also a way of life. They made it possible for a group of people to exist communally and to practice the unique faith that had forced them to leave their homeland. In their minds and in their lives the machine was always present, sustained by the clacking shuttles. 
Copyright of Annals of Iowa is the property of State of Iowa, by \& through the State Historical Society of Iowa and its content may not be copied or emailed to multiple sites or posted to a listserv without the copyright holder's express written permission. However, users may print, download, or email articles for individual use. 